\title{
Mercury in soil and attic dust as a reflection of Idrija mining and mineralization (Slovenia)
}

\section{Živo srebro v tleh in podstrešnem prahu v Idriji in okolici kot posledica orudenja in rudarjenja}

\author{
Mateja GOSAR \& Robert ŠAJN \\ Geološki zavod Slovenije, Dimičeva 14, 1001 Ljubljana, Slovenija \\ e-mail: mateja.gosar@geo-zs.si, robert.sajn@geo-zs.si
}

Ključne besede: živo srebro, Idrija, tla, podstrešni prah, onesnaženje, geokemija Key words: mercury, Idrija, soil, attic dust, pollution, geochemistry

\begin{abstract}
In Idrija and its close surroundings the influence of natural dispersion of mercury and of half-a-millenium mining on the environment have been studied. By sampling (69 soil and 65 attic dust samples) of a $51 \mathrm{~km}^{2}$ area it was established that on $17.4 \mathrm{~km}^{2} \mathrm{Hg}$ concentrations in soil exceed the critical values for soil $(10 \mathrm{mg} / \mathrm{kg})$. The estimated mercury mean for the studied area is $8.6 \mathrm{mg} / \mathrm{kg}(0.42-973 \mathrm{mg} / \mathrm{kg})$ for soil and $43.5 \mathrm{mg} / \mathrm{kg}(1.8-1055$ $\mathrm{mg} / \mathrm{kg}$ ) for attic dust. The $\mathrm{Hg}$ concentrations in attic dust are on an average 3.6 times higher than in soil. The highest ratios between $\mathrm{Hg}$ abundances in dust versus soil were found in the most distant localities and on higher altitudes above the sea level. $\mathrm{Hg}$ in soil exceeds $\mathrm{Hg}$ in attic dust only in localities in which the source of the metal is rock next to atmospheric emission.

The spatial $\mathrm{Hg}$ distribution in soil and attic dust correlate well $(\mathrm{r}=0.87)$ and depends very much upon morphology of terrain. High values occur in the Idrijca river valley and at base of slopes, while lower values prevail at higher elevations and at margins of the investigated area.
\end{abstract}

\section{Kratka vsebina}

Na območju Idrije in bližnje okolice smo raziskovali vpliv 500 letnega rudarjenja in naravnih danosti na stanje obremenjenosti okolja z živim srebrom. Z vzorčevanjem smo zajeli $51 \mathrm{~km}^{2}$ (69 vzorcev tal in 65 vzorcev podstrešnega prahu) in ugotovili, da na ozemlju velikem $17 \mathrm{~km}^{2}$ vsebnosti $\mathrm{Hg}$ v tleh presegajo kritično dovoljeno vrednost za tla (10 $\mathrm{mg} / \mathrm{kg})$. Vsebnost živega srebra na raziskanem območju znaša v tleh v povprečju $8.6 \mathrm{mg} / \mathrm{kg}$ $(0.42-973 \mathrm{mg} / \mathrm{kg})$ in $\mathrm{v}$ podstrešnem prahu $43.5 \mathrm{mg} / \mathrm{kg}(1.8-1055 \mathrm{mg} / \mathrm{kg})$. Vsebnosti $\mathrm{Hg} \mathrm{v}$ podstrešnem prahu so povprečno 3.6-krat višje kot v tleh. Najvišja razmerja med Hg v prahu in Hg v tleh smo določili na lokacijah najbolj oddaljenih od Idrije. V tleh je več Hg kot v prahu le na območjih, kjer je talna podlaga poleg atmosferskih emisij prevladujoči vir živega srebra.

Prostorski porazdelitvi Hg v tleh in podstrešnem prahu se dobro ujemata $(\mathrm{r}=0.87)$ in sta zelo odvisni od morfologije ozemlja. Visoke vrednosti so $\mathrm{v}$ dolini reke Idrijce in ob vznožju vzpetin, nižje vrednosti pa so v višjih delih in na obrobju obravnavanega ozemlja. 


\section{Introduction}

The Idrija mercury mine is situated 50 $\mathrm{km}$ west of Ljubljana, Slovenia, in the narrow valley of the Idrijca river and its confluent Nikova (Figure 1). The Idrija mine has been the second largest mercury mine in the world surpassed only by the Almaden mine (F e r r a r a, 1999). During the operating period of the mine, 107,000 tones of mercury were produced. By taking into account losses during mining and inefficient smelting, the total volume of mined mercury is estimated to be at least 147.000 tons (M l a k a r, 1974; M i kla v č i č, 1999). The Idrija mine is, after more than five hundred years of mining, in the final stage of its gradual shut down because of lack of reserves, low ore grade, low mercury prices and environmental reasons.

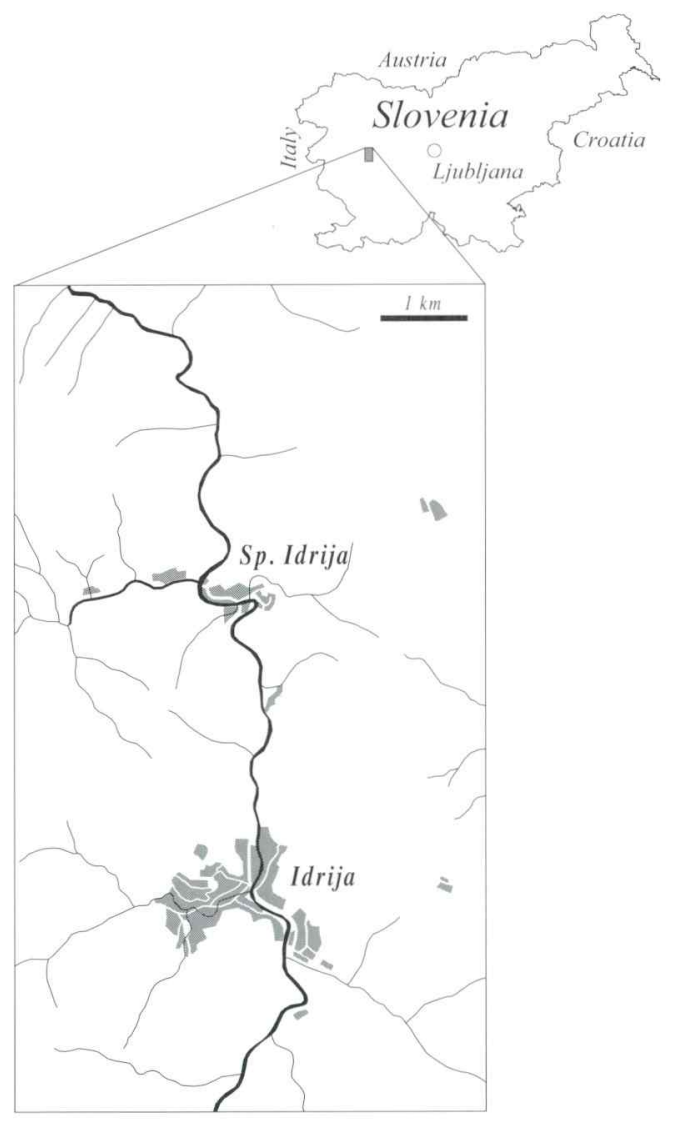

Figure1. Researched area

Slika 1. Lega raziskanega območje
Owing to naturally increased abundances of mercury in certain rocks, mining and ore procesing operations, Idrija and its surroundings have been polluted with $\mathrm{Hg}$. At the time of full mine and smelter production, about $20 \mathrm{~kg}$ of $\mathrm{Hg}$ were emited daily from the smelter chimney alone according to the estimate of Kosta et al. (1974), or $30 \mathrm{~kg}$ according to an estimate made by $\mathrm{K}$ a v č i č (1974).

The first known extensive mass intoxications with mercury occurred in Japan between 1953 and 1956, and in 1965 when in Minamata and Niigata more than 100 persons suffered heavy nervous system damages. It was established that the catastrophes were caused by $\mathrm{Hg}$ compounds that came into the marine environment with waste waters from the chemical factories ( $\mathrm{T}$ a k e uchi et al., 1963, in: Förstner \& M üll e r, 1974).

Outbreak of mass poisoning took place in Iraq in 1971/72. Seed grain treated with methylmercury fungicide was used to prepare homemade bread. More than 400 persons died, and several thousands of them were critically damaged (W H O , 1990).

These tragic ecological catastrophes warned the world about the heavy danger of intoxication with mercury and other toxic heavy metals. Most western European countries accepted very severe legislation on allowed levels of mercury and other metals in sediments, soils and food. Mercury came into focus of environmental investigations all around the world. Interest also arose in the geochemical mercury halo at Idrija, and detailed investigations on influence of mercury production on the environment were conducted (Byrne \& Kosta, 1970; Kosta et al., 1974; Dermelj, 1974; K a v či č, 1974).

\section{History of investigations of mercury envi- ronmental impact in Idrija}

Mercury pollution in the surroundings of the Idrija mine was studied by B y $\mathrm{r} n \mathrm{e}$ and K o s t a (1970). Mercury was determined in water, soil and plant samples taken at two localites in Idrija. In the area around the roasting plant, the established amounts of mercury in investigated plants were about 5 
times higher than in the Pront area (ore deposit outcrop), although soils at both localities contained about the same amounts of mercury (200 - $600 \mathrm{mg} / \mathrm{kg})$. They concluded that the finely dispersed mercury is easier assimilated than mercury from the ore particles in the soil of the Pront area. It is interesting, however, that the experimental determination of mercury available to plants did not show singnificant differences between the two localities. The river that flows through the town was also examined. The samples taken about $1 \mathrm{~km}$ above the plant contained between 0.1 and $1 \mathrm{ng} \mathrm{Hg} / \mathrm{ml}$. Those taken at two sites near and below the plant showed in case of still water little $\mathrm{Hg}$ $(0.5 \mathrm{ng} / \mathrm{ml})$ but turbulent water containing a suspension of fine ash particles gave values of 4 to $74 \mathrm{ng} \mathrm{Hg} / \mathrm{ml}$ (Byrne \& Kosta, 1970).

Studies of the distribution, uptake and transformation of mercury in the environment, plant life, animals and man in the area of Idrija and the site of an abandoned mine at Podljubelj are described by $\mathrm{K}$ o s t a et al. (1974). Important results on distribution of mercury in plants were obtained, especially on its accumulation and methylation. Studies of fish and aquatic life contributed new information on behavior of mercury and some other elements in animals. It was established that contamination of water in the Idrijca river is transferred to a large degree to water animals, whereas the degree of methylation increases with distance from the source (K o s t a et al., 1974; D e r m e l j, 1974). To obtain data on the degree of methylation in waters that carry away the roasted ore tailings, $\mathrm{Hg}$ in muscle and liver of trouts caught at Marof, Stopnik and at confluence of Bača into Idrijca were measured. It was interesting to note that total mercury determined in muscles of fishes fell of sharply downstream, while methylmercury in both organs remained roughly constant. Thus in muscle, the average methylmercury fraction rose from $15.5 \%$ at Marof over $83 \%$ at Stropnik to $98 \%$ at Most na Soči, while for liver methylmercury fraction was much lower (K o s t a et al., 1974). This increasing relative methylation is result of the rapid elimination of inorganic mercury and the long biological half life of the methyl form, and also of the increasing degree of meth- ylation in the aquatic system downstream (Kosta et al., 1974).

Mercury uptake, distribution and elimination were determined also in other animals (rabbits, hens) at the most exposed localities around the main stack (S te g n a r , 1973).

Measurements of mercury in the air during the 1970's, at the time of full production of the mine and roasting plant, showed very high values. By collecting 24-h samples during 1971-1972 at six localities in Idrija, $\mathrm{K}$ a v čič (1974) found values of 100-4,000 ng $\mathrm{Hg} / \mathrm{m}^{3}$ with mean of $2,000 \mathrm{ng} \mathrm{Hg} / \mathrm{m}^{3}$. In the smelter courtyard the contents were 10,000 to $30,000 \mathrm{ng} \mathrm{Hg} / \mathrm{m}^{3}$. A year later with a different analytical method at the roasting plant $8,500 \mathrm{ng} \mathrm{Hg} / \mathrm{m}^{3}$ was determined, and in the town center $570 \mathrm{Hg} / \mathrm{m}^{3}$ (G r a ši č, 1973; Ko s t a et al., 1974). There were great differences between the contents owing to weather changes. In the years 1986 ( $\mathrm{K}$ o b a 1 et al., 1991), 1991 (P i r c, 1991; L u p š i n a et al., 1992) and in 1992/93 (L u p š i $\mathrm{na}-\mathrm{Miklavčič,} \mathrm{1994)} \mathrm{drastic} \mathrm{drops} \mathrm{of}$ $\mathrm{Hg}$ in the air were found (all measurements below $500 \mathrm{ng} \mathrm{Hg} / \mathrm{m}^{3}$, and mostly below 300 $\mathrm{ng} \mathrm{Hg} / \mathrm{m}^{3}$ ) after the production of the mine and smelter had almost halted. Measurements in September 1994 with portable Zeeman atomic absorption spectrometer PA915 (Gos a r, 1997; Gos a r et al., 1997a) showed rather high mercury concentrations in the air in spite of the fact that the smeltery was stopped ten months before measurements and the only activity in the mine was ventilation. Concentrations above 300 $\mathrm{ng} \mathrm{Hg} / \mathrm{m}^{3}$ (in places even up to $2,000 \mathrm{ng}$ $\mathrm{Hg} / \mathrm{m}^{3}$ ) were observed in the surroundings of the two main sources of mercury vapors in Idrija. Three traverses of the same itinerary at various times were measured. The results show rapid variation of mercury in air, probably depending mostly upon rapidly changing weather conditions.

L u p šina et al. (1992) investigated mercury in lichens that are considered a confirmedly reliable bioindicator of air pollution. Samples were collected in six localities at Idrija, two in its surroundings, at the abandoned mine at Podljubelj and in the reference point in the Julian Alps. At Idrija very high concentrations in lichens were determined ( $\left.25-188 \mathrm{ng} \mathrm{Hg} / \mathrm{m}^{3}\right)$, with only 0.4 
$\mathrm{ng} \mathrm{Hg} / \mathrm{m}^{3}$ at the reference locality. In continuation of these studies (Miklavčič, 1999) next to lichens also garden vegetables were investigated (carrots and beans) in several localities in Idrija. In carrots $60-760$ ng $\mathrm{Hg} / \mathrm{g}$ dry sample was determined and in beans $2-23 \mathrm{ng} \mathrm{Hg} / \mathrm{g}$ d.s. The author considers that $\mathrm{Hg}$ in carrots reflects air pollution with $\mathrm{Hg}$, and the bean soil pollution. The study confirmed heavy mercury impact on the environment in Idrija in the 1990's after the closing down of mercury production.

Gna mu š (1992) presented in his work the use of biologic indicators for monitoring and assessing the mercury impact on terrestrial ecosystems. Total mercury concentrations in higher plants from the Idrija area were found above $1 \mathrm{mg} / \mathrm{kg}$ dry weight as an average of two samplings. At a somewhat more distant locality at Srednja Kanomlja they were about 100 times lower. In continuation of the study ( $\mathrm{Gn}$ a mus \& \& Hor vat, 1999; Gnamuš et al., 2000) also abundance of mercury in soil close to smeltery were determined (mean $1256 \mathrm{mg} / \mathrm{kg}$, $\mathrm{n}=14$ ) and in plants growing on them (mean $41.8 \mathrm{mg} / \mathrm{kg}$ ). In the wider surroundings of Idrija, the averages in soil amount to 288 $\mathrm{mg} / \mathrm{kg}(\mathrm{n}=96)$ and in plants to $14.4 \mathrm{mg} / \mathrm{kg}$ $(\mathrm{n}=48)$.

$\mathrm{Pal}$ inka š et al. (1995) report the results of the investigation of environmental pollution around the Idrija mercury mine on the basis of a two days field work (24 and 25 May 1990). Soils were sampled at 52 points arranged in an irregular grid. The maximum value $(87.6 \mathrm{mg} / \mathrm{kg})$ was determined in the mining area and in the vicinity of the smelter. The mean mercury concentration in the soil of the studied area was $15 \mathrm{mg} / \mathrm{kg}$. The distribution of mercury along four vertical profiles suggests a predominant influence of the fallout on the accumulation of the pollutant. An extremely low content of mercury in the stream waters and springs in the Idrija surrounding ( 3 - $31 \mathrm{ng} \mathrm{Hg/l)} \mathrm{ap-}$ proximates to the waters in the unpolluted areas and differs greatly from other mining areas. P a lin k a š et al. (1995) believe that these low values are due to high $\mathrm{pH}$ (7.5-8.3) of well-buffered waters, a characteristic of karst hydrology.

Results of study of $\mathrm{Hg}$ phases in tailings (Biester \& Gosar, 1999; Biester et al., 1999) indicate that the binding type of mercury is primarily dependent upon the efficiency of roasting technique and prevailing mercury species in roasted ore. In older tailings the predominant $\mathrm{Hg}$ species is cinnabar (HgS) due to incomplete roasting, whereas in tailings of the 20th century the amount of cinnabar in the material decreased because of higher efficiency of the rosting process and the increasing use of ores bearing native $\mathrm{Hg}$. In younger tailings metallic Hg sorbed to mineral matrix components became the predominant $\mathrm{Hg}$ binding form in addition to unbound $\mathrm{Hg}^{0}$ and traces of HgO. Despite the lower total Hg concentrations found in the younger tailings, the long-term risk potential of its mobile matrix-bound $\mathrm{Hg}^{0}$ is higher than in that of older tailings bearing mostly immobile cinnabar (B i e s ter et al., 1999).

Because most roasted ore tailings were dumped into the Idrijca riverbed, the contents of mercury in the sediments of Idrijca and Soča rivers (G o s a r, 1992; G o s a r , 1997; G o s a r et al., 1997b; B i es ter et al., 2000; H r ova t et al., 2000) and also in marine sediments at the mouth of the Soča river (Kosta et al., 1978; Covelli et al., 1999; Horvat et al., 1999; Širca et al., 1999a; Širca et al., 1999b; Biester et al., 2000; Covelli et al., 2001) are increased. Studies of mercury speciation in sediments (Biester et al., 2000) indicate the occurrence of two major $\mathrm{Hg}$ forms; cinnabar the primary ore, and an unspecified group of matrix-bound $\mathrm{Hg}$ compounds which were assumed to be potentially bioavailable. The results show that $\mathrm{Hg}$ concentrations and dispersion of the two $\mathrm{Hg}$ forms in sediments strongly depend on grain size. Accumulation of cinnabar predominately occurs in coarse grained river sediments, where it constitutes on average more than $80 \%$ of total $\mathrm{Hg}$ (up to $1,000 \mathrm{mg} / \mathrm{kg}$ ) in present- and past day sediments. In contrast noncinnabar $\mathrm{Hg}$ was found to be enriched in areas where fine grained material was deposited reaching up to $40 \%$ in flooded soils, and up to $55 \%$ in sediments of the Gulf of Trieste.

Hess (1991) investigated in the frame of a short study only a limited number of samples of soil, river sediments and water. In soil he found from 1.8 to $885 \mathrm{mg} \mathrm{Hg} / \mathrm{kg}$. Analyzed were also 4 river sediment sam- 
ples that contained comparable mercury as in soils, whereas the water samples contained 0.35 and $3.1 \mathrm{mg} \mathrm{Hg} / \mathrm{l}$.

Spatial distribution of mercury in soil on an $8 \times 14 \mathrm{~km}$ area with Idrija in the center was studied by Hes s (1993). Owing to topographic and meteorologic reasons the area was elongated in the north-south direction. He sampled in a regular $1 \mathrm{~km}$ grid (127 sample sites). On grassland he collected the upper $15 \mathrm{~cm}$ of soil, in the forest the upper $20 \mathrm{~cm}$, and on arable soil the upper 30 $\mathrm{cm}$ of the soil profile. In forest sample sites in which also the humus horizons were developed next to the mineral soil also the sample of the humus horizon was collected.

Contents above $10 \mathrm{mg} \mathrm{Hg} / \mathrm{kg}$ were detected in soils in valleys and at foot of slopes, and lower values in higher parts and at margins of the sampled area. In 10 selected samples also the contents of the most dangerous form of mercury, the methylated mercury was determined. Selected samples contained $<0.003$ to $0.2 \mathrm{mg}$ of methyl $\mathrm{Hg} / \mathrm{kg}$ which corresponds to a few thousandths to $0.66 \%$ of total mercury in samples.

\section{Methods and Materials}

The research by H e s s (1993) established the dimensions of the Idrija geochemical mercury halo, which is the result of outcropping of mineralized rocks and of half a millenium of mining and processing mercury ore. The impact of the mercury production even exceeds the naturally higher $\mathrm{Hg}$ geochemical background. In an area measuring approximately $3 \times 6 \mathrm{~km}$ with the town of Idrija in the heart of it, very high mercury concentrations in soil were determined. The sampling net used by Hess was not dense enough to separate the most polluted locations. In the year 2000 , we carried out a new geochemical research with a better coverage of the area. In the most affected areas, such as Idrija and Spodnja Idrija, we took an average of four samples in a $\mathrm{km}^{2}$. At a chosen location, we took a sample of the attic dust from a nearest suitable house as well as a sample of the soil in its immediate vicinity. We considered this sufficient for disclosing the most affected areas in Idrija and estimating the mercury contents in them.
In localities sampled by Hess, this study should document the possible changes that might have happened in the past ten years since Hess's investigation.

Soil was sampled from the surface to a depth of $15 \mathrm{~cm}$; the possible organic horizons were excluded. In the town itself, we sampled urban soil such as soil in the gardens and on the grass verges. In the surroundings of Idrija, we took samples from grasslands, only exceptionally, if there was no other possibility, we sampled forest soil. One soil sample represents the composite material sampled in the sampling point and four points $10 \mathrm{~m}$ towards $\mathrm{N}, \mathrm{E}, \mathrm{S}$ and $\mathrm{W}$. The mass of such a composite was about $1 \mathrm{~kg}$. There were 69 soil samples collected.

Of the three materials soil, sediment and dust, which derive primarily from the Earth's crust, and with which human beings come into contact, dust is the most pervasive. It is also the material that has, until last 20-30 years, largely been ignored as a significant source of trace metals in the urban environment. The term dust usually comprises street dust and house dust. However other types, such as playground dust, have also been studied (Ferguson \& Kim , 1991). The work of Š a j n (1999) represents an introduction of studies of urban sediments (street sediment, house and attic dust) into the geochemical studies in Slovenia. He also sampled a special type of house dust; attic dust. It represents dust that is deposited in the attics, which are abandoned by inhabitants, so that there should be minimal tenant influence on the dust deposited there. It is derived prevailingly from external sources as deposition of aerosols and dusting of soil, and less from household activities. Particles of house dust accumulate in the human organism through inhalation and consummation. In this manner, the intake of heavy metals into the organism also takes place (Schlipkoeter \& Broc$\mathrm{kh}$ a u s, 1988).

The attic dust as sampling material has the advantage that its composition remains constant, chemically unchanged with time. Investigations of attic dust chemistry reveal the average historical state of the atmosphere (Š a j n , 1999).

The attic dust was collected from wooden construction of attic that was not in imme- 
diate contact with roof tiles and floor. This permitted to avoid collecting particles of tiles, wood and other construction materials. For sampling buildings as old as possible were selected. We gathered 65 attic dust samples.

The samples were air-dried. A fraction of attic dust smaller than $0.125 \mathrm{~mm}$ was prepared for the chemical analyses by sieving. Soil samples were gently crushed in a ceramic mortar and passed through a sieve with $2 \mathrm{~mm}$ openings. Fraction smaller than $2 \mathrm{~mm}$ was pulverised before chemical analyses.

Samples were analyzed in the ACME laboratories in Vancouver, Canada. After aqua-regia digestion ( 1 hour, $95^{\circ} \mathrm{C}$ ) mercury was determined using Cold Vapor Atomic Absorption Spectrometry (CVAA). Quality assurance was carried out by shipment of samples to the laboratory in a random succession to distribute any errors due to laboratory performance. Objectivity was assured through the use of neutral laboratory numbers. Accuracy was estimated by blind determinations of geological standards SJS1, GXR-6 and SO-1. Reliability of determinations was assessed as very satisfactory.

\section{Results and Discussion}

On the basis of the investigated samples, the estimated mercury mean in the soil in Idrija and its surroundings amounts to 8.6 $\mathrm{mg} / \mathrm{kg}$ with the range from 0.42 to 973 $\mathrm{mg} / \mathrm{kg}$ and for attic dust $43.5 \mathrm{mg} / \mathrm{kg}$ with the range from 1.8 to $1055 \mathrm{mg} / \mathrm{kg}$. The Slovene average for soil is $0.15 \mathrm{mg} / \mathrm{kg}$ ( $\mathrm{Pirc}$, 1993) and for attic dust $1.1 \mathrm{mg} / \mathrm{kg}$ (Š a j $\mathrm{n}$, 1999). On $17.4 \mathrm{~km}^{2}$ of the studied area, the contents of mercury exceed the critical allowed value for mercury in soil $(10 \mathrm{mg} / \mathrm{kg}$, Official Gazette - Ur. list, 1996).

For comparison, we prepared geochemical maps of mercury distribution in same distribution classes for soil based on sampling in year 1990 by Hes s (1993) (Figure 2) and for soil and attic dust based on our sampling in year 2000 (Figures 3 and 4). As expected, the state of mercury impact on soils did not change much. The mercury levels of the year 1990 are comparable to those of 2000 . However, by means of denser sampling, we could better locate spots of especially high mercury impact (contents higher than 140 $\mathrm{mg} / \mathrm{kg}$ ). Spatial distribution of mercury in soil depends a lot upon morphology of the area (Figures 3 and 5). The highest mercury content in soil (973 mg/kg, site 507) occurs in the garden soil on Kosovelova Street 21. According to C a r (1998), rocks mineralized with elementary $\mathrm{Hg}$ and cinnabar are exposed at this location. Besides, the ancient dumps of unroasted ore also occur here ( $\breve{\mathrm{C}}$ a r, 1998). Close to this locality Hess (1991) found a similar concentration (885 $\mathrm{mg} / \mathrm{kg}$ ) in soil. The second highest concentration (924 mg/kg, site 518) was determined on Prejnuta where old ore roasting tailings are situated; the ore was roasted there from mid $17^{\text {th }}$ to mid $19^{\text {th }}$ century ( $\check{\mathrm{C}}$ a r , 1998). Here, the influence of exhaust from chimney stacks of roasting plant was also high. Detailed sampling revealed increased mercury content in the area around the last $500 \mathrm{~m}$ of the Ljubevšca brook. (between 40 and $67 \mathrm{mg} / \mathrm{kg}$ ), which can be probably attributed to the nearby ventilation shaft of the mine. On the Pšenk hill, SW from Idrija, one sample uncovered high mercury content (57 mg/kg) that can be the consequence of ore roasting in the woods in the past, as described by $\breve{C}$ a r (1998). Hess also sampled close-by, but he did not detect any higher contents.

Mercury contents in the attic dust are on average 3.6 times higher than in the soils. It is only in the locations where soil is, next to the atmospheric emissions, the main source of mercury, that the situation is reversed. That is on the locations of unsmelted ore wastes, primary ore smelting residues, ore residues dumps, outcropping of mineralised rocks and in locations of old ignition facilities or in places where the smelting residues were used for road construction or otherwise. These locations are described by $\check{\mathrm{C}}$ a r (1998)

The geographical distributions of mercury contents in the soil and attic dust are in good agreement (Figures 3 and 4). The correlation coefficient $(\mathrm{r})$ between contents in the two sampling media is 0.87 (Figure 6). There is also a strong correlation between $\mathrm{Hg}$ in soil and attic dust and the altitude ( $\mathrm{r}$ $=0.84$ respectively $\mathrm{r}=0.80 ;$ Figures 7 and 8 ). This suggests the conclusion that the pollution is spread mainly along the Idrijca val- 


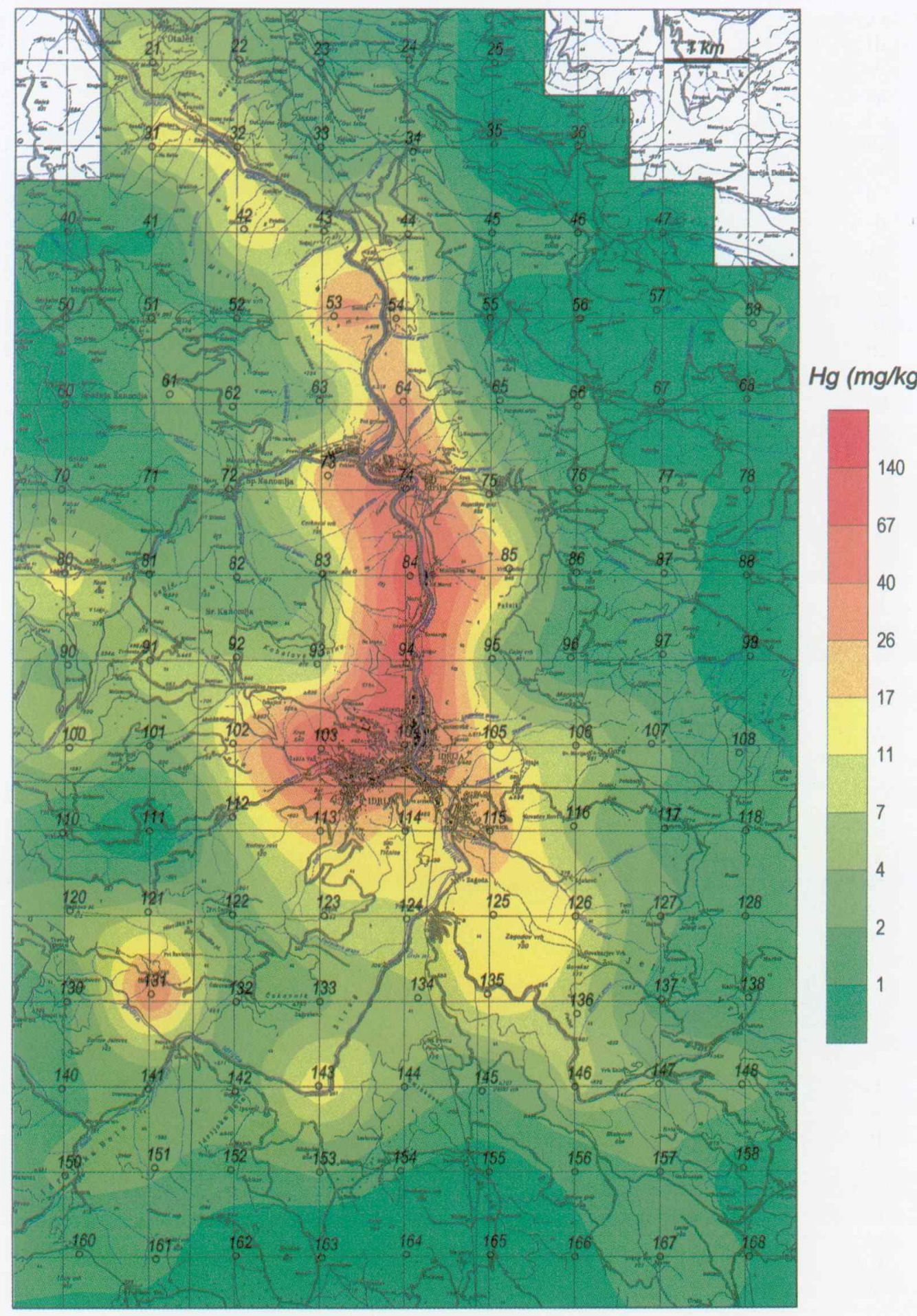

Figure 2. Mercury distribution in soil in year 1990 (data after He s s, 1993) Slika 2. Porazdelitev Hg v tleh v letu 1990 (podatki po H e s s u, 1993) 


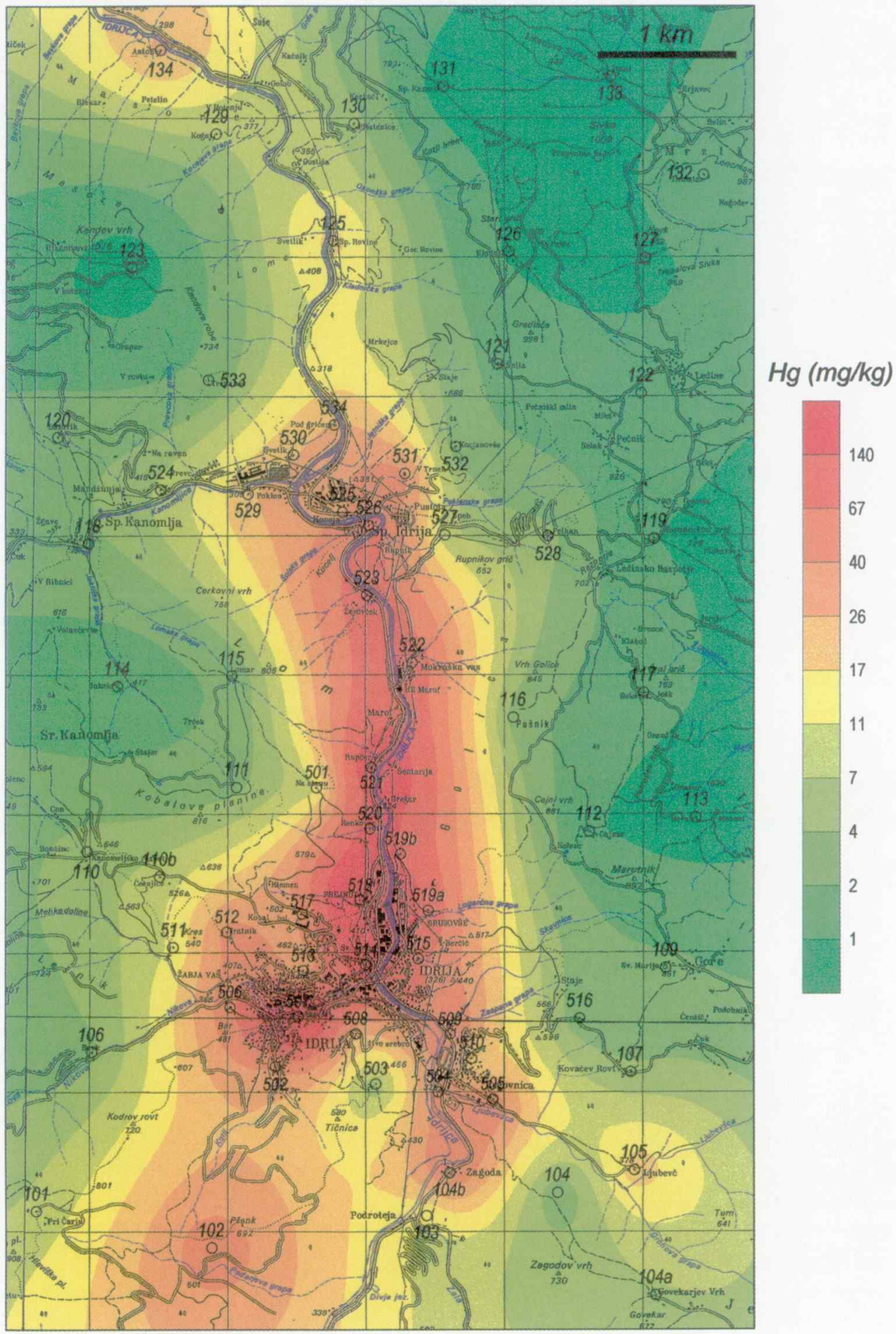

Figure 3. Mercury distribution in soil in year 2000

Slika 3. Porazdelitev Hg v tleh v letu 2000 


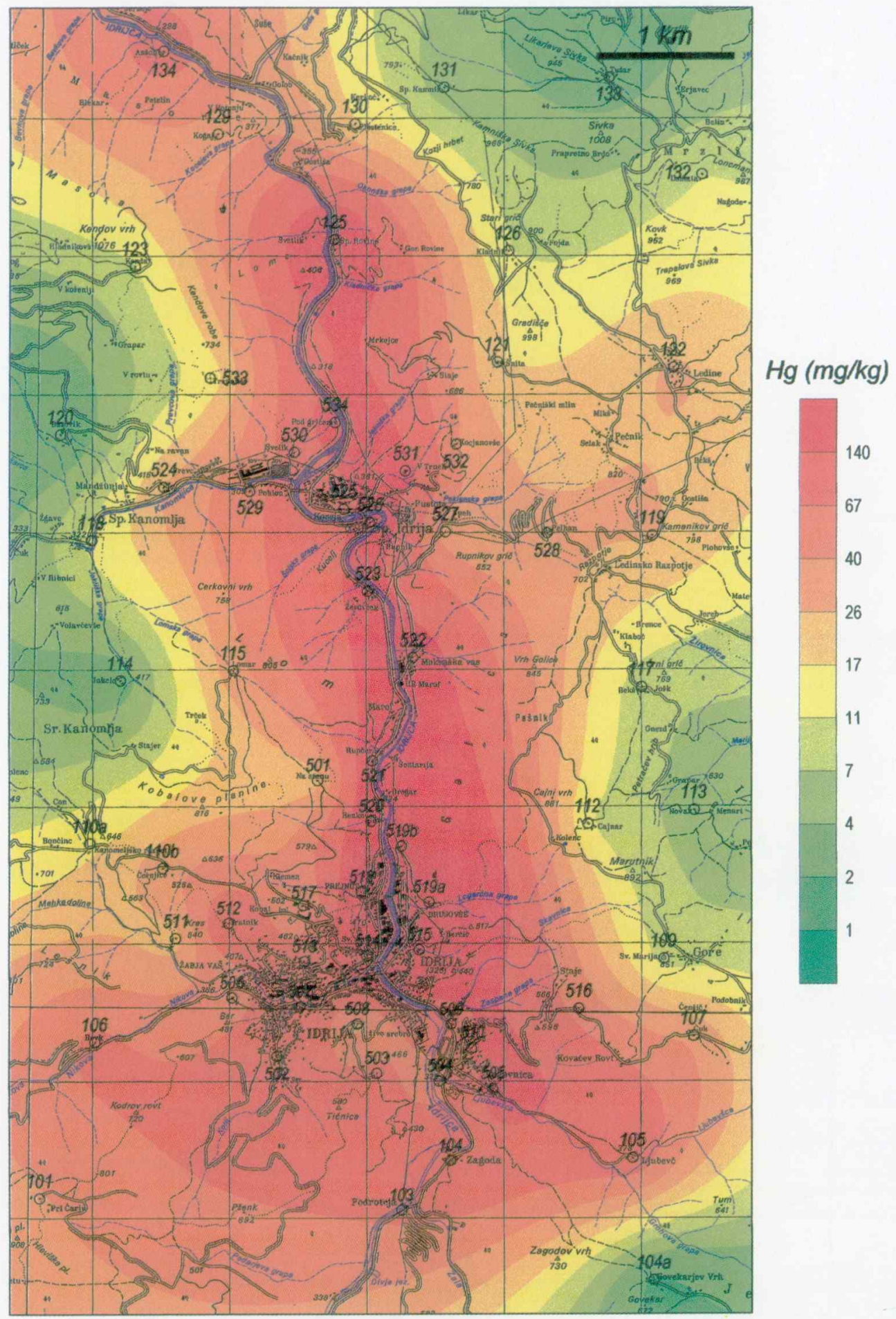

Figure 4. Mercury distribution in attic dust in year 2000

Slika 4. Porazdelitev Hg v podstrešnem prahu v letu 2000 


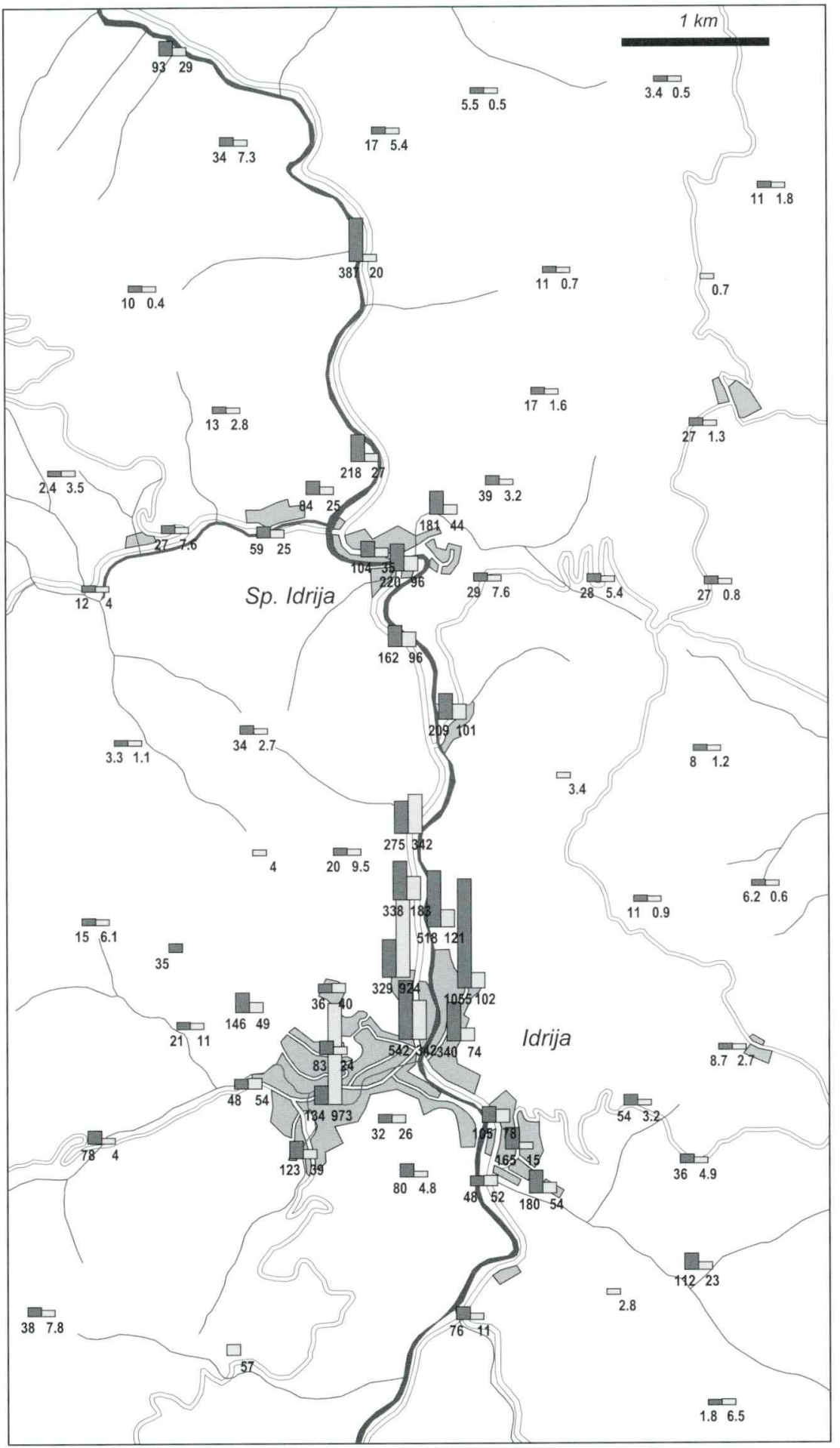

Figure 5. Mercury contents $(\mathrm{mg} / \mathrm{kg}$ ) in attic dust (dark grey columns) and in soil (light grey columns) Slika 5. Porazdelitev Hg (mg/kg) v podstrešnem prahu (temno sivi stolpci) in tleh (svetlo sivi stolpci) 


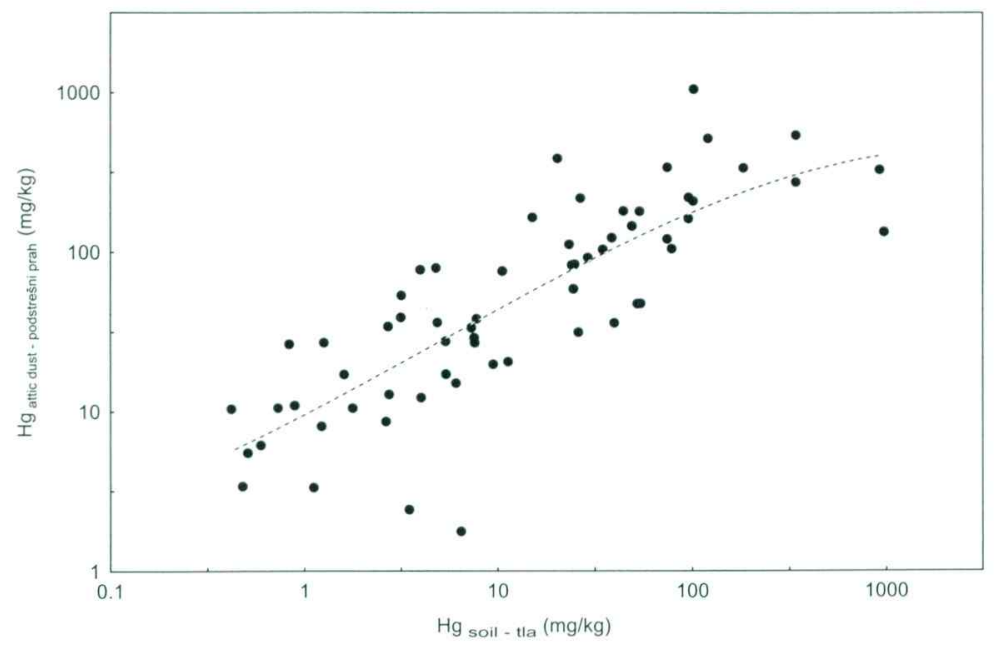

Figure 6. Relationship between $\mathrm{Hg}$ in attic dust and in soil

Slika 6. Soodvisnost $\mathrm{Hg}$ $\mathrm{v}$ podstrešnem prahu in $\mathrm{V}$ tleh

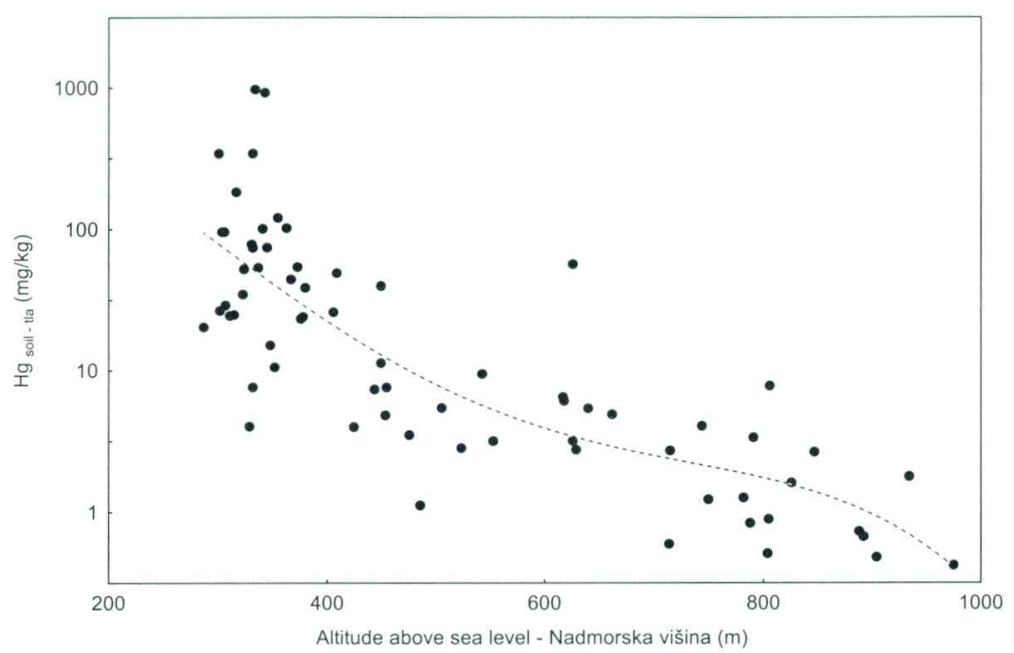

Figure 7. Distribution of $\mathrm{Hg}$ content in soil depended on altitude above sea level

Slika 7. Porazdelitev vsebnosti Hg v tleh v odvisnosti od nadmorske višine

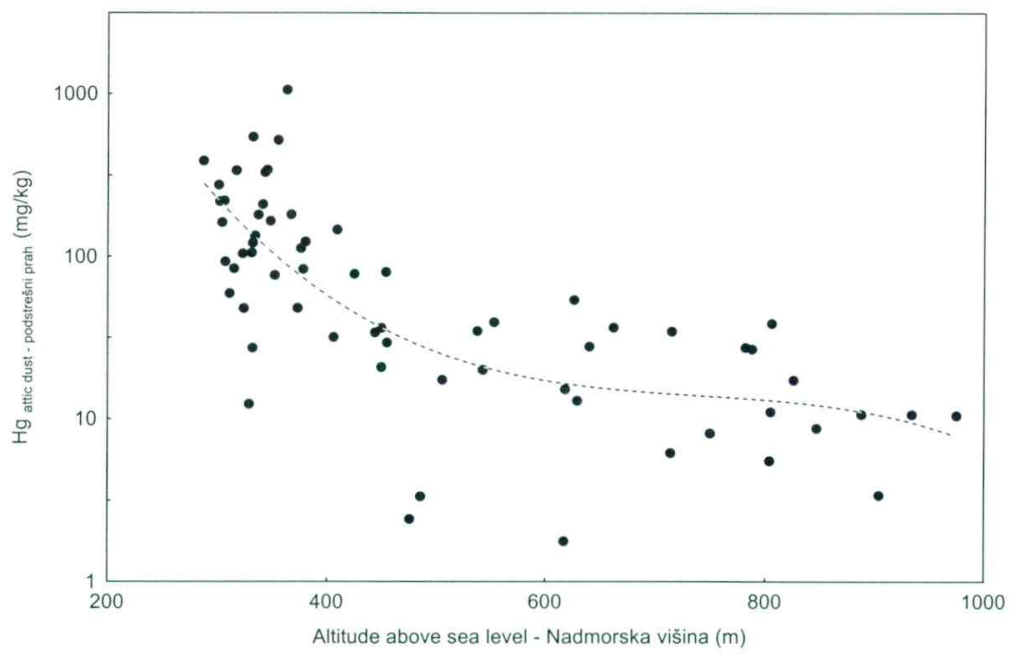

Figure 8. Distribution of $\mathrm{Hg}$ content in attic dust depended on altitude above sea level

Slika 8. Porazdelitev vsebnosti $\mathrm{Hg} v$ podstrešnem prahu $\mathrm{v}$ odvisnosti od nadmorske višine 


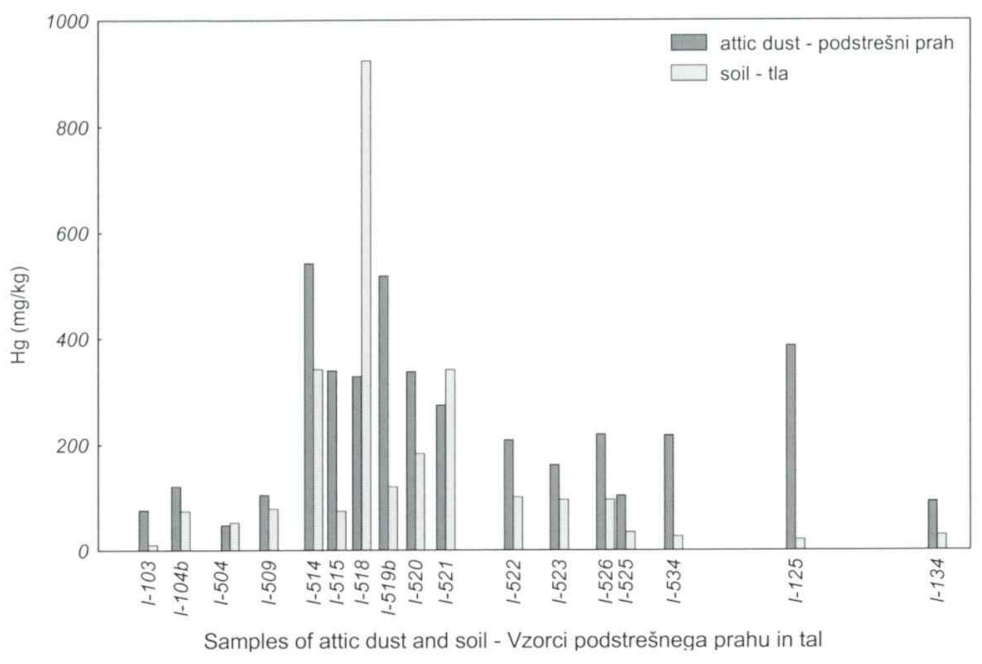

Figure 9. Hg in soil and attic dust in the Idrijea river valley from the confluence with Zala nothwards

Slika 9. Vsebnosti $\mathrm{Hg} \mathrm{v}$ tleh in podstrešnem prahu $\mathrm{v}$ dolini reke Idrijce od sotočja z Zalo proti severu ley, while the distant influence seems to be of secondary importance only.

Of particular interest are the data of mercury contents in the attic dust. The map of mercury distribution in the attic dust (Figure 4) shows that the influence of atmospheric emissions caused by the Idrija smelter extended outside the researched area. Obviously, the impact on environment was also considered on the regional scale.

Extremely high contents in the attic dust were determined in the vicinity of the smoke stack $(1055 \mathrm{mg} / \mathrm{kg})$ and in the valley of Idrijca between the Idrijca bridge in Idrija and the hydroelectric power plant Marof (from 275 do $542 \mathrm{mg} / \mathrm{kg}$ )(Figures 5 and 9). Prevailing southern winds spread the pollution from the smeltery far northwards along the Idrijca valley (Figure 9). High mercury contents occur also in the Ljubevšca valley, probably owing to the ventilation shaft situated there.

It is of special interest to compare the $\mathrm{Hg}$ samples taken higher or lower than the main exhaust stack of the smelter. The average of $\mathrm{Hg}$ in soil, which lies in lower altitudes than the main exhaust stack, is $42 \mathrm{mg} / \mathrm{kg}$ and in the attic dust samples is $122 \mathrm{mg} / \mathrm{kg}$. In higher altitudes the average is 2.8 for soil and $16 \mathrm{mg} / \mathrm{kg}$ for attic dust.

Concentration ratios (Fergusson \& $\mathrm{K} \mathrm{i} \mathrm{m,1991)} \mathrm{of} \mathrm{mercury} \mathrm{in} \mathrm{the} \mathrm{attic} \mathrm{dust} \mathrm{and}$ soil, respectively, are significantly dependant on the altitude. Lower from the altitude of the main exhaust stack the concentration ratio average is about 3 , and in higher elevations it is about 7 , which is similar to the Slovene concentration ratio (7.3) (Figure 10). In localities of pronounced atmospheric emissions, the $\mathrm{Hg}$ contents in the attic dust are much higher than in the corresponding soils. The highest ratios were determined at the most distant localities that lie most frequently also at highest altitudes (sampling points $119,123,122,106$ )

In the case of Idrija, the attic dust was first used for geochemical mapping of a small area at a dense spacing. It proved itself a very applicable and stable sampling medium showing small variability at short distances.

\section{Mechanisms of mercury dispersion in Idrija}

Mechanisms of mercury dispersion in Idrija and its surroundings are of various nature. The most important mercury sources are atmospheric emissions, ore and smelting residue dumps, and outcrops of mineralized rocks.

The main cause of $\mathrm{Hg}$ pollution in Idrija and its surroundings were the atmospheric emissions. The strongest sources - smeltery and roasting tailings dumps - are on the north edge of the town of Idrija where by the winds prevailing in the north-south direction, with a emphasized southern component (P e tkovš e k \& R a kovec, 1980), the polluted gases and dust particles are spread mainly along the Idrijca valley north 
of Idrija, and much less southwards. This is evident also from Figure 9 showing the concentrations of mercury in soil and attic dust along the Idrijca valley. Since that valley is bordered by steep slopes of relative elevation reaching even above $700 \mathrm{~m}$, the polluted air is directed mostly northwards along the valley, and not eastwards or westwards. The second important source of atmospheric emissions are the two ventilation shafts of the mine. At the Inzaghi shaft in the center of Idrija also after abandoning of production high mercury concentrations in the air were measured (Gos a r et al., 1997a; M i k l a v či č, 1999). The second shaft in the Ljubevšca valley should not have much influence, as indicated by established mercury in carrots (M i k l a v č i č, 1999). On the displayed mercury distributions in attic dust and soil (Figures 3 and 4), however, increase of mercury in the Ljubevšca valley is evident.

The other causes of mercury pollution are mineralized rock dumps and especially smelting residues that still contain rather high amounts of mercury. The main reason for complex spatial distribution of roasting tailings in Idrija and surroundings are changes in combustion technology over centuries, continuous growth of quantities of processed ore accompanied by decreasing $\mathrm{Hg}$ content and various method of further treatment of ore residues ( $\breve{\mathrm{C}}$ a r , 1998). Up to the middle of $17^{\text {th }}$ century, the ore was roasted on the neighboring hills (Pront, Pringl), and in more distant localities ( $\mathrm{Ce}$ kovnik, Kanomlja). Several localities of old ignition facilities were found by Mlakar during geological mapping, others were located later ( $\mathrm{C}$ a r , 1998). The first established permanent roasting plant was at Lenštat. In 1652, the roasting plant at Prejnuta was built. It was in operation till the $19^{\text {th }}$ century. After 1868, the new roasting plant at Brusovš was gradually installed. Until 1977, most roasting remains were dumped directly into the river Idrijca that carried the material to the Soča river and Adriatic Sea. In this way, extensive river deposits with high mercury contents that are and will continue to be a source of mercury impacted sediments also in the future were formed in the lower Idrijca valley (G o s a r, 1997; Gosar et al., 1997b; Biester et al., $2000)$. New dumps of roasted ore occur also on the right banks of Idrijca. After the renewal of production in 1983 dumping of tailings into the river was not allowed ( $\breve{\mathrm{C}}$ a r , 1998). At rainshowers nevertheless polluted material was washed into the drainage. Spatial distribution of roasting remains was described by $\breve{C}$ a r (1998). The highest mercury contents in soil (sites 518 and in part $507)$ we attribute to roasted material.

Mercury levels in the environment at Idrija are increased also owing to natural, geogene reasons. Syngenetically mineralized and lithologically very diverse Ladinian beds were deposited in sedimentation conditions of the tectonic graben of the Idrija structure. They were deposited on partly eroded older Anisian, Scythian, Permian and Carboniferous rocks that were epigenetically mineralized ( M l a k a r, 1967; P l a c e r \& Č a r, 1977; C̆ a r 1985; Č a r, 1998). During later tectonic events the present very complex structure of the deposit formed. However, a more extensive natural migration of mercury into the wider surroundings of the deposit was limited owing to impermeable Carboniferous clastites and to tectonic zones filled with clay (Č a r , 1998). The western part of the deposit was uplifted along a fault and by erosion a part of mineralized rocks, especially of the Carboniferous clastites with native mercury, and at western edge the tectonized Skonca beds and tuffites were exposed ( $\breve{\mathrm{C}} \mathrm{a} \mathrm{r}, 1998)$. On an average the mineralized clastites contain $0.38 \% \mathrm{Hg}$, about half in the from of cinnabar, and the rest as native metal ( $\breve{\mathrm{C}}$ a r , 1998).

Carboniferous beds, enriched with cinnabar and native $\mathrm{Hg}$, lie below the center of Idrija, and they outcrop in slopes of Kurji vrh and lower part of Pront (C a r, 1998). The Skonca beds and tuffites are exposed on Pront between Karnik and Albreht (Č a r, 1998).

The results of our investigations lead to the conclusion that Idrija with its surroundings represents an environment that is highly polluted with mercury. It is an example of a case study in the frame of which the impacts of natural (geogene) sources of mercury, as well as those caused by human activity during the five hundred years long exploitation, can be studied in a relatively small area. 


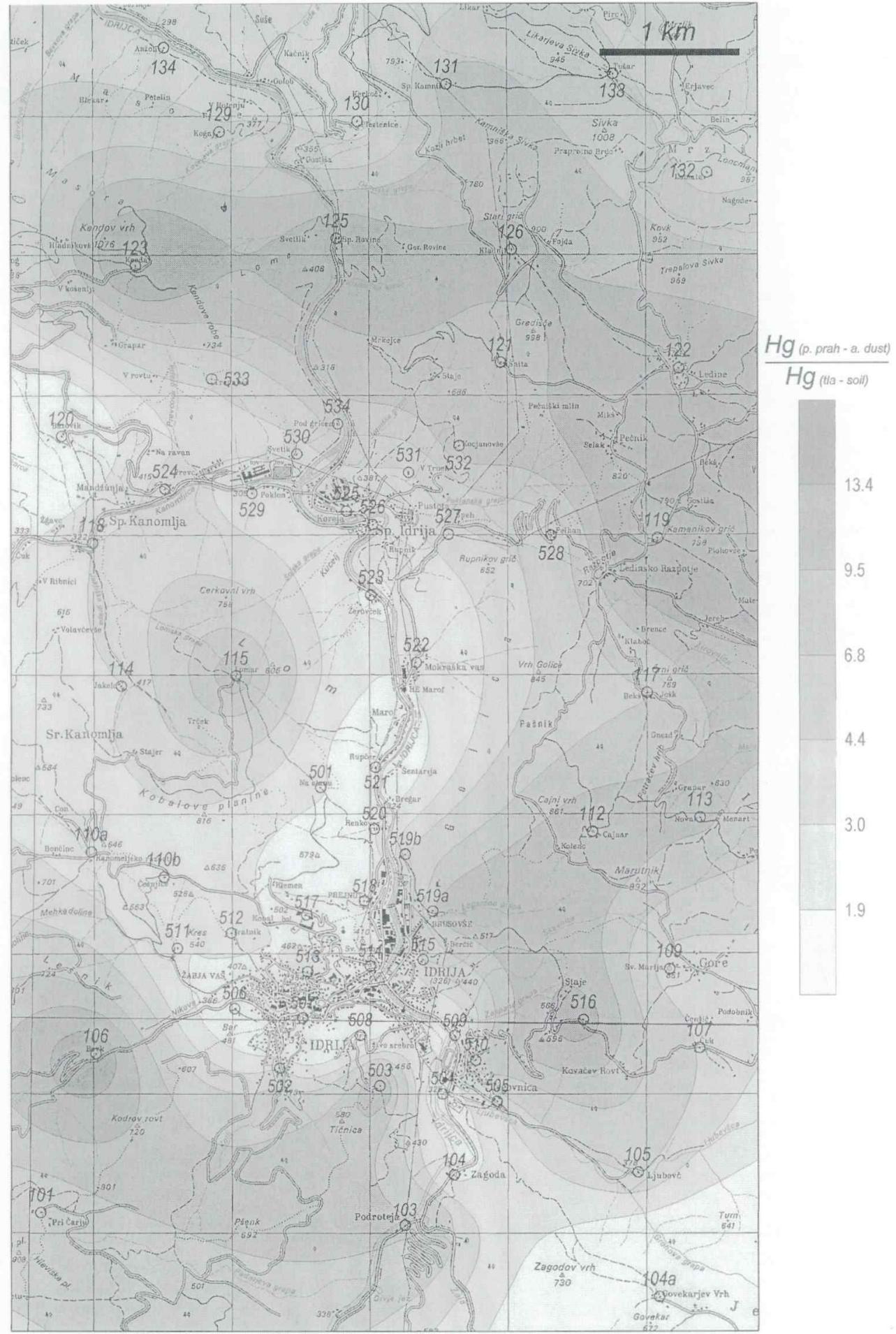

Figure 10. Spatial presentation of ratio of $\mathrm{Hg}$ in attic dust to $\mathrm{Hg}$ in soil. Slika 10. Prostorski prikaz razmerja Hg v podstrešnem prahu proti $\mathrm{Hg}$ v tleh 


\section{Acknowledgements}

We are grateful to dr. Bojan Ogorelec for his advices concerning the organisation of the article, and to prof. dr. Simon Pirc for translation of the article into English. The research was supported by The Ministry of Science and Technology of the Republic of Slovenia.

\section{Zivo srebro $\mathrm{v}$ tleh in podstrešnem prahu v Idriji in okolici kot posledica orudenja in rudarjenja}

\section{Uvod}

Rudnik živega srebra v Idriji leži v ozki dolini med idrijskim hribovjem in se razprostira med reko Idrijco in njenim pritokom Nikovo (slika 1). Glede na celotno proizvodnjo živega srebra prekaša Idrijo samo rudnik v španskem Almadenu (F e r r a r a, 1999). V celotni zgodovini rudnika so idrijski rudarji pridobili 107.000 ton živega srebra. Upoštevajoč vse ocenjene izgube, do katerih je prihajalo zlasti v starejših obdobjih, pa bi lahko znašala celotna proizvodnja živega srebra kar 147.000 ton (M l a k a r, 1974; M i k l a v č i č 1999). Po več kot petsto letih delovanja je danes idrijski rudnik zaradi izčrpanosti, nizke cene živega srebra na svetovnem tržišču ter okoljevarstvenih razlogov v zadnji fazi postopnega zapiranja.

Zaradi naravno povečane vsebnosti živega srebra $v$ nekaterih kamninah ter zaradi rudniške in predelovalne dejavnosti je širša okolica Idrije onesnažena s to kovino. Samo iz dimnika topilnice je pred letom 1977, ko sta rudnik in topilnica delovala še v polni meri, po oceni Kos te in sodelavcev (1974) uhajalo v atmosfero okrog $20 \mathrm{~kg}$ živega srebra na dan, ali po oceni Kavčičeve (1974) $30 \mathrm{~kg}$ živega srebra na dan.

Do prvih znanih velikih množičnih zastrupitev z živim srebrom je prišlo na Japonskem v letih 1953 do 1956 in 1965, ko je v Minamati in Niigati zbolelo več kot 100 ljudi za težkimi poškodbami živčnega sistema. Ugotovili so, da so katastrofe povzročile različne $\mathrm{Hg}$ spojine, ki so z odpadnimi vodami kemičnih tovarn prihajale $\mathrm{v}$ morsko okolje (Takeuchi et al., 1963 v: Först ner \& M üller, 1974).
Pozimi 1971/1972 je prišlo v Iraku do množične zastrupitve s kruhom iz moke zrnja, ki so bila prej obdelana s fungicidom metilnega Hg. Umrlo je več kot 400 ljudi, nekaj tisoč pa jih je bilo resno poškodovanih (W H O, 1990).

Ti tragični primeri so opozorili svet na veliko nevarnost zastrupitev z živim srebrom in drugimi nevarnimi težkimi kovinami. $V$ večini zahodnoevropskih držav so sprejeli zelo stroge predpise o dovoljenih količinah $\mathrm{Hg}$ in drugih kovin v sedimentih, tleh in hrani. Živo srebro se je znašlo v središču ekoloških raziskav po celem svetu. Za raziskovalce je postala tako tudi z ekološkega stališča zelo zanimiva idrijska živosrebrova geokemična avreola. Zato so se začele $\mathrm{v}$ tistem času poglobljene raziskave o vplivu rudarjenja, ki je bilo takrat še v polnem zamahu, na okolje (Byrne \& Kos t a, 1970; Kost a et al., 1974; D ermelj, 1974; K a v či č , 1974).

\section{Zgodovina raziskav obremenjenosti okolja z živim srebrom v Idriji}

Onesnaženost okolja z živim srebrom v okolici idrijskega rudnika sta raziskovala Byrne in Kosta (1970). Vsebnosti Hg so bile določene v vzorcih voda, tal in rastlin na dveh mestih v Idriji. Prva lokacija v bližini topilnice je bila onesnažena $\mathrm{z}$ drobno razpršenim elementarnim živim srebrom v zraku, druga lokacija pa je znana pod lokalnim imenom Pront, kjer izdanjajo karbonski skrilavi glinavei in meljevei s samorodnim živim srebrom. Ugotovili so, da so na območju topilnice količine živega srebra v preiskovanih rastlinah približno 5-krat večje kot na Prontu, kljub temu, da so tla na obeh območjih vsebovala podobne količine živega srebra (200 - $600 \mathrm{mg} / \mathrm{kg})$. Sklepali so, da se drobno dispergirano živo srebro v okolici topilnice dosti laže asimilira v rastlinah kot tisto na območju Pronta. Zanimivo je, da poskus določitve rastlinam dostopnega živega srebra ni pokazal značilnih razlik med obema lokacijama. V okviru iste raziskave so določili tudi koncentracije živega srebra $\mathrm{v}$ vodi reke Idrijce. Kilometer nad topilnico rude so izmerili od 0,1 do $1 \mathrm{ng} \mathrm{Hg} / \mathrm{ml}$, v bližini in tik pod njo so izmerili $0.5 \mathrm{ng} / \mathrm{ml} \mathrm{v}$ mirni vodi in $\mathrm{v}$ primeru turbulentnih tokov 
v vodi z drobno suspendiranimi delci od 4 do $74 \mathrm{ng} \mathrm{Hg} / \mathrm{ml}$ (B y r ne \& Kosta, 1970).

Raziskave o porazdelitvi, privzemu in presnovah živega srebra v okolju, vegetaciji, živalih in ljudeh na območju Idrije v primerjavi z okolico opuščenega rudnika so opravili Kosta in sodelavei (1974). Pomembni so rezultati o porazdelitvi živega srebra v rastlinah, zlasti o njegovi akumulaciji in metilaciji. Raziskave vodnih živali so pokazale, da se kontaminacija reke Idrijce $\mathrm{v}$ veliki meri prenaša na njih; stopnja metilacije v ribah narašča $z$ oddaljenostjo od izvora (Kosta et el., 1974; D ermelj, 1974). Da bi dobili podatke o stopnji metilacije v vodah, ki odplavljajo prežgano rudo, so analizirali meso in jetra postrvi, ulovljenih pri Marofu, Stopniku in pred izlivom Bače v Idrijco. Zanimivo je, da vsebnost celotnega živega srebra v mišicah rib s tokom reke pada, medtem ko razmerje med metilnim živim srebrom in celotnim živim srebrom $\mathrm{v}$ mesu rib narašča od $15,5 \%$ pri Marofu do $83 \%$ pri Stropniku in $98 \%$ pri Mostu na Soči. To pomeni, da je $\mathrm{v}$ mesu rib, ulovljenih pri Mostu na Soči, skoraj vse živo srebro v metilni obliki, medtem ko je to razmerje $\mathrm{v}$ jetrih rib znatno nižje (K o s t a et al., 1974). Porast razmerja med organsko in anorgansko vezanim živim srebrom pripisuje D e r m elj (1974) hitremu izločanju anorgansko vezanega $\mathrm{Hg}$, dolgi biološki razpolovni dobi metilnega živega srebra in tudi povečani stopnji metilacije $\mathrm{v}$ vodnem sistemu spodnjega toka Idrijce.

Privzemanje, razdelitev in izločanje živega srebra so merili tudi na nekaterih drugih živalih (zajci, kokoši) na najbolj izpostavljenih mestih v bližini glavnega dimnika topilnice (S t e g $\mathrm{n}$ a r, 1973).

Meritve v zraku iz 70-ih let, ko sta rudnik in topilnica še polno obratovala, so pokazale zelo visoke vsebnosti živega srebra. K a v či č e va (1974) je proučevala stopnjo onesnaženosti zraka v letih 1971/72. Jemali so 24 -urne vzorce in določili na 6 vzorčnih mestih v Idriji od 100 do 4.000 , povprečno $2.000 \mathrm{ng} \mathrm{Hg} / \mathrm{m}^{3}$. $\mathrm{Na}$ dvorišču topilnice so določili kar od 10.000 do $30.000 \mathrm{ng} \mathrm{Hg} / \mathrm{m}^{3}$. Leto kasneje so $\mathrm{z}$ drugo metodo pri topilnici izmerili $8.500 \mathrm{ng} \mathrm{Hg} / \mathrm{m}^{3}$, v centru mesta pa $570 \mathrm{ng} \mathrm{Hg} / \mathrm{m}^{3}$ (G r a ši č, 1973 ; K o s t a et al., 1974). Ugotovili so tudi, da prihaja zaradi spremenjenih vremenskih pogojev med posameznimi meritvami do precejšnjih razlik. V letih 1986 (Kobal et al., 1991), 1991 (P ir c, 1991; L u pšina et al., 1992) in $1992 / 93$ (L u pšina-Miklavčič, 1994) so meritve pokazale veliko zmanjšanje količine živega srebra v zraku (vse pod $500 \mathrm{ng} / \mathrm{m}^{3}$, večina celo pod $300 \mathrm{ng} / \mathrm{m}^{3}$ ). To je razumljivo, saj sta topilnica rude in rudnik $\mathrm{v}$ tem času delovala v zelo zmanjšanem obsegu. Meritve septembra 1994 s prenosnim spektrometrom PA-915 (Gosar, 1997; G o s a r et al., 1997a) so pokazale, da so bile koncentracije Hg v zraku še vedno precej visoke, kljub temu, da predelovalnica rude že več kot deset mesecev pred meritvami ni delovala in da je bila $\mathrm{v}$ času meritev edina dejavnost rudnika prezračevanje. Koncentracije nad $300 \mathrm{ng} \mathrm{Hg} / \mathrm{m}^{3}$ zraka (ponekod tudi do $2.000 \mathrm{ng} \mathrm{Hg} / \mathrm{m}^{3}$ zraka) so bile izmerjene v okolici obeh glavnih virov $\mathrm{Hg}$ hlapov v Idriji. Izmerjeni so bili trije profili na isti poti ob različnih časovnih obdobjih. Prikazujejo hitro spreminjanje koncentracij živega srebra $\mathrm{v}$ zraku, verjetno predvsem $\mathrm{v}$ odvisnosti od hitro se spreminjajočih vremenskih pogojev.

Vesna Lupšina in sodelavci (1992) so raziskovali vsebnosti živega srebra v lišajih, ki so priznano dober bioindikator onesnaženja zraka. Lišaje so nabrali na šestih vzorěnih lokacijah v Idriji, dveh v bližnji okolici Idrije, v Podljubelju (opuščeni rudnik živega srebra) in na referenčnem mestu v Julijskih Alpah. V Idriji so izmerili zelo visoke koncentracije živega srebra v lišaju (od 25 do 188 kg/g), medtem ko je bila koncentracija na referenčnem mestu le $0,4 \mu \mathrm{g} / \mathrm{g}$. V nadaljevanju teh raziskav ( $\mathrm{Miklavčič,}$ 1999) so bile poleg lišajev obravnavane še nekatere vrtnine (korenje in fižol) na različnih lokacijah v Idriji. V korenju je bilo določeno od 60 do $760 \mathrm{ng} \mathrm{Hg} / \mathrm{g}$ v suhi snovi, v fižolu pa 2 do $23 \mathrm{ng} \mathrm{Hg} / \mathrm{g}$ v suhi snovi. Avtorica je mnenja, da odraža vsebnost $\mathrm{Hg} \mathrm{v}$ korenju nivo živega srebra v zraku, vsebnost Hg v fižolu pa nivo Hg v tleh. Vsekakor je raziskava potrdila veliko obremenjenost okolja v Idriji z živim srebrom tudi v devetdesetih letih 20. stoletja, ko v Idriji ni bilo več proizvodnje $\mathrm{Hg}$.

Gnamuř (1992) je izdelal diplomsko nalogo, v kateri je predstavil uporabo bioloških indikatorjev za spremljanje in vrednotenje obremenjenosti kopenskih ekosiste- 
mov z živim srebrom. Celotne koncentracije živega srebra $\mathrm{v}$ višjih rastlinah z območja Idrije so bile v povprečju dveh vzorčenj nad $1 \mathrm{mg} / \mathrm{kg}$ suhe teže. Na nekoliko oddaljenejši lokaciji v Srednji Kanomlji so bile te približno 100-krat manjše. V nadaljevanju raziskav (Gnamuř \& Horvat, 1999; Gna$\mathrm{m} u$ š et al., 2000) so bile določene tudi koncentracije živega srebra $\mathrm{v}$ tleh $\mathrm{v}$ bližini topilnice (povprečno $2456 \mathrm{mg} / \mathrm{kg}, \mathrm{n}=14$ ) in $\mathrm{v}$ rastlinah v bližini topilnice (povprečno 41,8 $\mathrm{mg} / \mathrm{kg})$. Na širšem območju mesta Idrija so izmerili v tleh povprečno $288 \mathrm{mg} / \mathrm{kg} \mathrm{Hg}$ $(\mathrm{n}=96)$ in $\mathrm{v}$ rastlinah povprečno $14,4 \mathrm{mg} / \mathrm{kg}$ $(\mathrm{n}=48)$.

Pa linka š s sodelavci (1995) poroča o rezultatih raziskave onesnaženosti okolja $\mathrm{v}$ bližini rudnika na podlagi dvodnevnega terenskega dela (24. in 25. 5. 1990). Tla so vzorčevali na 52 vzorčnih mestih v nepravilni mreži. Največje izmerjene koncentracije $(87,6 \mathrm{mg} / \mathrm{kg})$ so bile določene na antropogenih tleh in regosolih na območju rudnika in v bližini topilnice. Da bi ločili naravno stanje od antropogeno povzročenega, so preiskali 4 talne profile. Porazdelitev živega srebra v profilih nakazuje večinoma antropogeni, z zračnim depozitom pogojeni vnos živega srebra v tla. Povprečje talnih vzorcev je $15 \mathrm{mg} / \mathrm{kg}$, kar priča o veliki obremenitvi območja. V vzorcih vod in vodnih izvirov so določili zelo nizke vsebnosti živega srebra (3 $-31 \mathrm{ng} / \mathrm{l}$ ). Avtorji ugotavljajo, da je to zelo nenavadno ter da vode $\mathrm{v}$ bližini drugih rudnikov živega srebra vsebujejo bistveno višje koncentracije $\mathrm{Hg}$, zato interpretirajo nizke koncentracije kot posledico nevtralnega do rahlo bazičnega okolja ( $\mathrm{pH}$ med 7.5 in 8.3), ki ga povzroča karbonatno zaledje.

Rezultati raziskave zvrsti živega srebra v prežgani rudi kažejo (B i ester \& Gos a r, 1999; B i e s t er et al., 1999), da so vrste vezave $\mathrm{Hg}$ odvisne predvsem od učinkovitosti žgalne tehnike in prevladujočih zvrsti Hg v žgani rudi. V starih deponijah prevladuje cinabarit, v deponijah iz 20. stoletja pa je vsebnost cinabarita zelo majhna. To je posledica učinkovitejšega žganja in predelave karbonskih skrilavcev, ki vsebujejo samorodno živo srebro. V teh deponijah prevladuje $\mathrm{Hg}^{0}$, ki je vezano na mineralne komponente osnove, poleg tega pa nastopata še nevezan $\mathrm{Hg}^{0}$ in v sledovih HgO. Kljub temu, da vsebujejo mlajše deponije manj celotne- ga $\mathrm{Hg}$, so dolgoročno lahko bolj nevarne za okolje kot starejše, v katerih je Hg trdno vezan v cinabaritu (B i e s t e r et al., 1999).

Ker so večino žgalniških ostankov vsipavali v strugo Idrijce, so vsebnosti živega srebra v sedimentih reke Idrijce in Soče (G o sar, 1992; Gosar, 1997; Gosar et al., 1997b, Biester et al., 2000; Horvat et al., 2000) ter tudi v morskih sedimentih ob ustju reke Soče (Kosta et al., 1978; C ovelli et al., 1999; Horvat et al., 1999; Širca et al., 1999a; Širca et al., 1999b; Biester et al., 2000; Covelli et al., 2001) povišane. Študija speciacij živega srebra v sedimentih (Biester et al., 2000) je pokazala, da nastopa živo srebro v dveh oblikah: kot cinabarit in kot $\mathrm{Hg}$, vezan na komponente osnove (ne-cinabaritna frakcija). Vsebnost ne-cinabaritne frakcije je močno odvisna od zrnavosti sedimenta. Akumulacija cinabarita nastopa v bolj debelozrnatih rečnih sedimentih, kjer je več kot $80 \% \mathrm{Hg}$ vezanega $v$ cinabaritu. Ne-cinabaritne komponente pa so vezane na lokacije, kjer se kopiči najdrobnejši sediment: $v$ poplavnih ravnicah je ne-cinabaritnega deleža do $40 \%$, v Tržaškem zalivu pa do $55 \%$.

Hess (1991) je v okviru kratke študije preiskal nekaj vzorcev tal, rečnih sedimentov ter vode. $V$ tleh je ugotovil od 1,8 do 885 $\mathrm{mg} \mathrm{Hg} / \mathrm{kg}$, štirje vzorci rečnih sedimentov kažejo podobno vsebnost kot tla, vzorca vode pa sta vsebovala 0,35 in $3,1 \mu \mathrm{g} \mathrm{Hg} / \mathrm{l}$.

Prostorsko razporeditev koncentracij $\mathrm{Hg}$ v tleh na ozemlju velikem $8 \times 14 \mathrm{~km}$ z Idrijo v sredini je raziskoval Hess (1993). Vzorčeval je v pravilni mreži 1 x 1 km (127 vzorčnih lokacij) in sicer na travnikih prvih 15 $\mathrm{cm}$ tal, v gozdu prvih $20 \mathrm{~cm}$ in na oranih tleh prvih $30 \mathrm{~cm}$ tal. V gozdu, kjer so bili razviti tudi humusni horizonti, je bil na vsaki lokaciji vzet poleg vzorca mineralnega dela tal še vzorec humusnega horizonta.

Vrednosti nad $10 \mathrm{mg} \mathrm{Hg} / \mathrm{kg}$ tal so v dolinah in ob vznožju vzpetin, nižje vrednosti pa so v višjih delih in na obrobju obravnavanega ozemlja. Najvišja vrednost je bila izmerjena $\mathrm{v}$ vzorcu s skrajnega severnega roba Idrije v dolini Idrijce (148,2 $\mathrm{mg} \mathrm{Hg} / \mathrm{kg}$ ), najnižje vrednosti $(0,2 \mathrm{mg} \mathrm{Hg} / \mathrm{kg})$ pa v severovzhodnih in južnih predelih obravnavanega ozemlja (H e s s , 1993).

$\mathrm{V}$ desetih vzorcih je bila določena tudi količina najbolj nevarne oblike $\mathrm{Hg}$ - metil- 
no živo srebro (skupno dimetilno $-\mathrm{CH}_{3}-\mathrm{Hg}$ $\mathrm{CH}_{3}$ in monometilno $\mathrm{CH}_{3}-\mathrm{Hg}^{+}$). Vsebujejo od manj kot 0,003 pa do $0,2 \mathrm{mg}$ metilnega $\mathrm{Hg} / \mathrm{kg}$, kar ustreza od nekaj tisočink pa do $0,66 \%$ celotnega Hg v vzorcih. Aritmetična srednja vrednost $\mathrm{v}$ analiziranih vzorcih je 0,065 $\mathrm{mg}$ metilnega $\mathrm{Hg} / \mathrm{kg}$ in jo presegata le dva vzorca: vzorec humusa iz doline reke Idrijce med Idrijo in Spodnjo Idrijo, ki vsebuje kar 0,2 mg metilnega $\mathrm{Hg} / \mathrm{kg}(0,13 \%$ celotnega $\mathrm{Hg}$ ), in vzorec mineralnega dela tal iz doline zgornjega toka Idrijce $(0,12 \mathrm{mg}$ metilnega $\mathrm{Hg} / \mathrm{kg} ; 0,66 \%$ celotnega $\mathrm{Hg}$ ). Statistično značilne korelacije med celotno količino $\mathrm{Hg} v \mathrm{v}$ vzorcih in vsebnostjo metilnega živega srebra v vzorcih niso ugotovili. Delež metilnega $\mathrm{Hg}$ je $\mathrm{v}$ primerjavi s celotnim živim srebrom v vzorcih razmeroma majhen, v vseh vzorcih pod $0,7 \%$ (H e s s , 1993).

\section{Metode in materiali}

S študijo Hess a (1993) je bila ugotovljena razsežnost idrijske živosrebrove geokemične avreole, ki je nastala zaradi naravnih danosti (izdanjanja rudonosnih kamnin) in zaradi pol tisočletja trajajočega rudniškega in topilniškega delovanja, katerega vpliv je zasenčil naravno povišano geokemično ozadje za Hg. Na območju velikem približno $3 \times 6 \mathrm{~km}$ z Idrijo v sredini so bile ugotovljene zelo visoke koncentracije $\mathrm{Hg} v \mathrm{v}$ tleh. Ker pa takratna mreža vzorčevanja ni bila dovolj gosta, da bi ločila najbolj obremenjene lokacije, smo v letu 2000 opravili novo geokemično raziskavo $\mathrm{z}$ gostejšo mrežo vzorčevanja. $\mathrm{Na}$ najbolj obremenjenih območjih v Idriji in Spodnji Idriji smo vzorčevanje pogostili tako, da smo vzeli približno 4 vzorce na $\mathrm{km}^{2}$. Na naključno izbranih lokacijah smo vzeli vzorec podstrešnega prahu v najbližji ustrezni hiši ter v neposredni bližini hiše še vzorec tal. Predvidevamo, da je to dovolj, za določitev najbolj obremenjenih površin v Idriji in nivoja $\mathrm{Hg} v$ njih. Na lokacijah, kjer je vzorčeval že Hess, pa študija dokumentira tudi morebitne spremembe, ki jih je prineslo zadnje 10 letno obdobje od njegovega vzorčevanja.

Tla so bila vzorčena do globine $15 \mathrm{~cm}$, brez morebitnega organskega horizonta. Izven naselij smo vzorčevali travniška tla (le izjemoma gozdna, če travnika ni bilo v bli- žini), v naseljih pa urbana tla (vrtna tla in tla obcestnih zelenic). Posamezen vzorec je predstavljal kompozit vzorca v osrednji točki in štirih $10 \mathrm{~m}$ oddaljenih točkah severno, vzhodno, južno in zahodno od osrednje. Celotni tako zbrani vzorec tal je tehtal približno $1 \mathrm{~kg}$. Skupno smo raziskali 69 vzorcev tako odvzetih tal.

Podstrešni prah je v geokemične raziskave v Sloveniji vpeljal Šajn (1999). Predstavlja zvrst bivalnega prahu, ki se kopiči na podstrešjih. To je v prostorih, kjer se prebivalci zelo redko ali sploh ne zadržujejo in na katere vsakdanja dejavnost prebivalcev nima večjega vpliva. Izvira pretežno iz zunanjih virov, kot sta usedanje aerosolov in prašenje tal ter podrejeno iz gospodinjskih dejavnosti. Delci bivalnega prahu se z vdihavanjem ali zaužitjem kopičijo v človeškem organizmu. Na ta način s prahom vnašamo v organizem tudi težke kovine (S chlipkoeter \& Brockhaus, 1988).

Pomen podstrešnega prahu kot vzorčnega sredstva je $v$ tem, da predstavlja edino snov, ki je ostala ohranjena in kemično nespremenjena skozi daljši čas. Raziskave kemizma podstrešnega prahu odkrivajo povprečno stanje ozračja v preteklosti (Š a jn , 1999).

Podstrešni prah smo vzorčevali tako, da smo zbrali prah z lesene konstrukcije podstrešja, ki ni bila $\mathrm{v}$ neposrednem stiku s strešniki ali tlemi. Na ta način smo se izognili pobiranju delcev strešnikov, ostankov lesa in gradbenih materialov. Pri vzorčenju podstrešnega prahu smo izbrali čim starejše objekte. Skupno smo odvzeli 65 vzorcev podstrešnega prahu.

Zbrani vzorci so bili posušeni na zraku. Za kemijsko analizo podstrešnega prahu smo s sejanjem pripravili frakcijo manjšo od $0.125 \mathrm{~mm}$. Talni vzorci so bili presejani skozi sito $\mathrm{z}$ velikostjo odprtin $2 \mathrm{~mm}$, presevek pa zmlet na analizno zrnavost.

Vzorci so bili analizirani v laboratoriju ACME v Vancouvru v Kanadi. Za določitev vsebnosti $\mathrm{Hg}$ je bilo $0.5 \mathrm{~g}$ vzorca prelito s 3 ml zlatotopke (mešanica kislin $\mathrm{HCl}: \mathrm{HNO}_{3}$ : $\mathrm{H}_{2} \mathrm{O}$ v razmerju $3: 1: 2$ ), eno uro segrevano na $95^{\circ} \mathrm{C}$ in potem razredčeno do $100 \mathrm{ml} \mathrm{z}$ destilirano vodo. $\mathrm{V}$ raztopini je bila določena vsebnost Hg z neplamensko AAS. Vzorce in naključno izbrane dvojnike ter geološke standardne materiale smo poslali v labora- 
torij po naključnem vrstnem zaporedju. S tem smo zagotovili nepristranskost analitike in enakomerno porazdelitev morebitnega spreminjanja analiznih pogojev preko vseh vzorcev. Zanesljivost kemičnih analiz smo ocenili kot zelo zadovoljivo.

\section{Rezultati in razprava}

Na podlagi raziskanih vzorcev znaša ocenjeno povprečje živega srebra na območju Idrije v tleh $8.6 \mathrm{mg} / \mathrm{kg}$ in niha v razponu od 0.42 do $973 \mathrm{mg} / \mathrm{kg}$ in $\mathrm{v}$ podstrešnem prahu $43.5 \mathrm{mg} / \mathrm{kg}$ od najnižje vrednosti 1.8 do najvišje $1055 \mathrm{mg} / \mathrm{kg}$. Slovensko povprečje za tla znaša $0.15 \mathrm{mg} / \mathrm{kg}$ (Pirc, 1993) in za podstrešni prah $1.1 \mathrm{mg} / \mathrm{kg}$ (Š a jn, 1999). Kar na $17,4 \mathrm{~km}^{2}$ obravnavanega ozemlja vsebnosti v tleh presegajo kritično dovoljeno vrednost za $\mathrm{Hg} \mathrm{v}$ tleh $(10 \mathrm{mg} / \mathrm{kg}$ Ur.list R S, 1996).

$\mathrm{Za}$ lažjo primerjavo smo v enakih porazdelitvenih razredih pripravili geokemične karte porazdelitve Hg v tleh na podlagi podatkov vzorčevanja leta 1990 (H e s s , 1993) (slika 2) in geokemične karte porazdelitve $\mathrm{Hg}$ v tleh in podstrešnem prahu na podlagi našega vzorčevanja leta 2000 (sliki 3 in 4). Stanje obremenjenosti tal se v desetih letih, kot smo tudi pričakavali, ni bistveno spremenilo. Nivo Hg je v tleh v letu 1990 zelo primerljiv s stanjem v letu 2000. Smo pa z gostejšim vzorčevanjem v lanskem letu uspeli določiti lokacije, ki so še posebno obremenjene s Hg (koncentracije večje od 140 $\mathrm{mg} / \mathrm{kg}$ ). Prostorska razporeditev živega srebra $v$ tleh je zelo odvisna od morfologije ozemlja (sliki 3 in 5). Najvišja koncentracija živega srebra v tleh $(973 \mathrm{mg} / \mathrm{kg})$ je bila določena v vzorcu št. 507. To so vrtna tla na Kosovelovi ulici $21 \mathrm{v}$ Idriji. Po podatkih Č a r j a (1998) je omenjena lokacija na robu izdanjanja orudenih kamnin, ki vsebujejo tako elementerno živo srebro kot tisto vezano $\mathrm{v}$ cinabaritu. Poleg tega segajo na to območje tudi orudeni neprežgani odvali (Č a r , 1998). V neposredni bližini omenjene lokacije je podobno koncentracijo $\mathrm{v}$ tleh (885 mg/kg) določil tudi H es s (1991). Drugo najvišjo koncentracijo $\mathrm{Hg}(924 \mathrm{mg} / \mathrm{kg})$ smo določili na Prejnuti (vzorec št. 518). Tu so prisotni primarni žgalniški ostanki, saj so tam rudo žgali od sredine 17. do sredine 19. stoletja, žgalniški ostanki pa so se kopičili v okolici (C a r , 1998). Na tem območju je bil velik tudi neposreden vpliv dimnih plinov iz topilnice. Nadalje se je pri podrobnejšem vzorčevanju pokazalo povišanje vsebnosti Hg v območju med zadnjimi 500 m Ljubevšce in Idrijco (vrednosti med 40 in $67 \mathrm{mg} / \mathrm{kg}$ ), kar gre morda pripisati vplivu prezračevalnega jaška, ki je $\mathrm{v}$ bližini. $\mathrm{Z}$ enim vzorcem smo ugotovili povišane vrednosti $\mathrm{Hg}$ tudi na območju hriba Pšenk, JZ od Idrije. Verjetno tako visoka koncentracija živega srebra (57 $\mathrm{mg} / \mathrm{kg}$ ) ni posledica atmosferskih emisij ali naravnih danosti, ker na tem območju ne izdanjajo rudonosne kamnine. Lahko pa je posledica žganja rude $\mathrm{v}$ preteklosti po gozdovih, kot omenja Č a r (1998). V bližini je vzorčeval tudi Hess, a povišanja vrednosti ni zaznal.

Vsebnosti Hg v podstrešnem prahu so v povprečju za 3.6-krat višje kot v tleh. Živega srebra je več v tleh kot v prahu le na lokacijah, kjer je njegov poglavitni vir poleg atmosferskih emisij tudi talna podlaga. To je na prej omenjenih deponijah starih prežganih in neprežganih rudniških odvalov, na območju izdanjanja rudonosnih kamnin ter na lokacijah, kjer so žgali rudo v prejšnjih stoletjih ali uporabljali žgalniške ostanke v cestogradnji in podobno. Lokacije s povečano vsebnostjo živega srebra $\mathrm{v}$ talni podlagi je opisal Č a r (1998).

Porazdelitvi $\mathrm{Hg}$ v podstrešnem prahu in v tleh $\mathrm{v}$ Idriji in okolici sta si zelo podobni (sliki 3 in 4). Korelacijski koeficijent (r) med vsebnostjo $\mathrm{Hg}$ v obeh vzorčnih sredstvih znaša 0.87 (slika 6). Močno povezavo smo odkrili tudi med vsebnostjo $\mathrm{Hg} v$ tleh in v podstrešnem prahu ter nadmorsko višino (r $=0.84$ oz. $\mathrm{r}=0.80$; sliki 7 in 8 ). Iz tega lahko sklepamo, da je onesnaženje vezano predvsem na dolino reke Idrijce, daljinski vpliv pa je podrejenega pomena.

Se posebno so zanimive vsebnosti živega srebra v podstrešnem prahu. $\mathrm{Na}$ karti porazdelitve $\mathrm{Hg}$ v njem (slika 4) je razvidno, da je vpliv rudniške, predvsem topilniške dejavnosti zaznaven še izven robov raziskanega ozemlja in da je bil vpliv rudarjenja $\mathrm{v}$ Idriji pomemben tudi v regionalnem merilu.

Najvišje vsebnosti Hg v podstrešnem prahu so bile določene v neposredni bližini topilnice $(1055 \mathrm{mg} / \mathrm{kg})$ in $\mathrm{v}$ dolini Idrijce od sotočja z Nikovo do HE Marof (vsebnosti od 
275 do $542 \mathrm{mg} / \mathrm{kg}$ ) (sliki 5 in 9). Zaradi prevladujočih južnih vetrov se je onesnaženje širilo od glavnega vira onesnaženja, to je od topilnice, po dolini Idrijce daleč proti severu. To je lepo razvidno iz porazdelitve vsebnosti živega srebra v vzorcih tal in podstrešnega prahu, ki je prikazana na sliki 9 . Visoke so tudi vsebnosti v dolini Ljubevšce, kar je verjetno odraz prezračevalnega jaška $\mathrm{v}$ tej dolini.

Zelo zanimiva je tudi primerjava vsebnosti živega srebra v vzorcih, ki leže nižje oz. višje od topilniškega dimnika. Ocenjeno povprečje $\mathrm{Hg} \mathrm{v}$ vzorcih tal oz. podstrešnega prahu, ki so nižje od dimnika znaša $42 \mathrm{oz}$. $122 \mathrm{mg} / \mathrm{kg}$, v vzorcih zbranih višje od dimi$\mathrm{ka}$ pa $2.8 \mathrm{mg} / \mathrm{kg} \mathrm{v}$ tleh in $16 \mathrm{mg} / \mathrm{kg} \mathrm{v}$ podstrešnem prahu. Razvidno je, da vsebnosti Hg v tleh rečne doline za 15-krat presegajo vsebnosti v okolici, v podstrešnem prahu pa za skoraj 8-krat.

Ugotovili smo tudi, da je obogatitveni odnos (Fergusson \& Kim, 1991) med $\mathrm{Hg}$ v podstrešnem prahu in $\mathrm{Hg}$ v tleh odvisen od nadmorske višine. Pod dimnikom je vsebnost $\mathrm{Hg}$ v podstrešnem prahu za 3 -krat večja kot $\mathrm{v}$ tleh, nad dimnikom pa več kot 7-krat, kar je podobno razmerju slovenskih povprečij (7.3) (slika 10). Na lokacijah, kjer so bile za obremenitve okolja najpomembnejše atmosferske emisije, so vsebnosti v podstrešnem prahu mnogo višje kot $\mathrm{v}$ tleh na isti lokaciji. Najvišja razmerja med $\mathrm{Hg}$ v prahu in $\mathrm{Hg}$ v tleh smo ugotovili na najbolj oddaljenih lokacijah, ki so navadno tudi na višji nadmorski višini (npr.vzorci št. 119, 123, 122, 106)

$\mathrm{Na}$ območju Idrije smo prvič uporabili podstrešni prah za geokemično kartiranje z gosto mrežo vzorčevanja na majhnem območju. Izkazal se je kot izjemno uporabno in za geokemično kartiranje zelo stabilno vzorčno sredstvo z nizkim deležem variance na majhnih razdaljah.

\section{Mehanizmi razširjanja živega srebra v Idriji}

$\mathrm{Na}$ podlagi raziskav o razširjenosti $\mathrm{Hg} \mathrm{v}$ okolju v preteklosti in na podlagi naših meritev lahko ugotovimo, da so mehanizmi razširjanja živega srebra in vzroki kontaminacije okolja z njim na Idrijskem mnogovr- stne narave. Najpomembnejši viri živega srebra so: atmosferske emisije, odvali rude in žgalniških ostankov ter izdanki rudonosnih kamnin.

V samem mestu Idrija in bližnji okolici so bile pomembne atmosferske emisije. Samo iz dimnika topilnice je pred letom 1977, ko sta rudnik in topilnica delovala še $\mathrm{v}$ polni meri uhajalo $\mathrm{v}$ atmosfero okrog $20 \mathrm{~kg}$ Hg/dan (Kosta et al., 1974; K a v čič, 1974). Zato so bile glavni vzrok obremenjenosti okolja z živim srebrom v Idriji in njeni okolici atmosferske emisije. Ker je bil najpomembnejši vir onesnaženega zraka topilnica z odlagališčem žgalniških ostankov, na severnem robu Idrije, kjer prevladujejo vetrovi v smeri sever-jug s poudarjeno južno komponento (P e tkovš ek \& R a kovec, 1980), so se onesnaženi plini in prašni delci širili v glavnem po dolini Idrijce severno od Idrije. To je razvidno tudi s slike 9 , kjer so prikazane koncentracije $\mathrm{Hg} \mathrm{v}$ tleh in podstrešnem prahu vzdolž doline Idrijce. Ker dolino Idrijce omejujejo strma pobočja z višinsko razliko tudi več kot $700 \mathrm{~m}$, se širi onesnažen zrak predvsem po dolini. Drugi pomemben vir atmosferskih emisij $\mathrm{Hg}$ sta prezračevalna jaška. Ob jašku Inzaghi, ki leži v centru mesta Idrija, so bile tudi v času po ukinitvi proizvodnje živega srebra v Idriji izmerjene visoke vsebnosti živega srebra v zraku (Go sar et al., 1997a; M i k l a v č i č, 1999). Prezračevalni jašek v dolini Ljubevšce naj po mnenju M i k lav č i č e ve (1999), glede na vsebnosti Hg v korenju, ne bi imel velikega vpliva. Vsebnosti Hg $\mathrm{v}$ podstrešnem prahu in tleh (sliki 3 in 4) pa kažejo povišane koncentracije $\mathrm{Hg} \mathrm{v}$ dolini Ljubevšce, ki jih verjetno lahko pripišemo vplivu tega zračnika.

Drugi vzrok obremenitve okolja z živim srebrom so odvali rude in predvsem odvali žgalniških ostankov, ki vsebujejo še precej $\mathrm{Hg}$. Osnovni vzrok za veliko razširjenost in zapleteno prostorsko razporeditev žgalniških ostankov v Idriji in njeni okolici je v načinu žganja rude $\mathrm{v}$ preteklosti in uporabi žgalniških ostankov $\mathrm{v}$ gradbene namene $\mathrm{v}$ povojnem obdobju (Č a r , 1998). Do srede 17. stoletja so žgali rudo na bližnjih gričih Pront, Pringl, pa tudi na bolj oddaljenih krajih v Čekovniku in Kanomlji, o čemer pričajo številni ostanki razbite lončevine. Več lokacij starih žgalnic je našel I. Mlakar 
pri geološkem kartiranju idrijske okolice, nekaj pa so jih našli tudi kasneje ( $\check{C}$ a r , 1998). Prva trajneje locirana žgalnica v mestu je bila na Lenštatu. Leta 1652 so začeli graditi žgalnico na Prejnuti, ki je delovala vse do 19. stoletja. Po letu 1868 so postopoma zgradili novo žgalnico na Brusovšu, na Prejnuti pa so žganje opustili. Večino žgalniških ostankov so potem vse do leta 1977 neposredno vsipavali v Idrijco, ki je material ob visokih vodah odnašala po dolini Idrijce in Soče v Jadransko morje. Tako so v spodnjem toku Idrijce nastali obsežni rečni nanosi z visokimi vsebnostmi Hg (Gos a r, 1997; G o s a r et al., 1997b; B i es ter et al., 2000), ki so in bodo vir $\mathrm{z}$ živim srebrom obremenjenega sedimenta tudi v prihodnosti. Nastale pa so tudi nove deponije prežgane rude vzdolž desnega brega Idrijce. Po obnovitvi proizvodnje po letu 1983 zaradi ekoloških razlogov ni bilo več dovoljeno vsipavati žgalniških ostankov v strugo Idrijce (Č a r, 1998). Kljub temu pa se je zaradi slabo utrjenih brežin ob večjih nalivih spiral material v Idrijco še naprej. Prostorsko razporeditev žgalniških ostankov je prikazal C̆ a r (1998). Najvišje koncentracije Hg, ki smo jih določili v obravnavanih talnih vzorcih (lokacija 518 in delno lokacija 507) smo pripisali vplivu žganiških ostankov.

Raven živega srebra je v okolju na Idrijskem povečana tudi zaradi naravnih - geogenih dejavnikov. Singenetsko orudene anizijske in litološko pestro razvite ladinijske plasti so nastajale v svojskih sedimentacijskih pogojih tektonskega jarka idrijske srednjetiasne tektonske zgradbe. Odložene so na erodirane starejše anizijske, skitijske, permijske in karbonske kamnine, ki so epigenetsko orudene (Mlaka r, 1967; Pla-

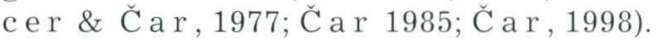
Pri kasnejših tektonskih dogajanjih je nastala današnja izjemno zapletena zgradba rudišča. Za preprečitev obsežnejše naravne migracije živega srebra v širšo okolico je pomembno predvsem to, da je rudišče obdano z neprepustnimi karbonskimi klastičnimi kamninami ali pa omejeno z zaglinjenimi tektonskimi conami (Č a r , 1998). Zahodni del rudišča je bil ob prelomu dvignjen, tako da je erozija odkrila del orudenih kamnin, predvsem karbonske klastite s samorodnim živim srebrom ter ob skrajnem zahodnem obrobju rudišča tudi pretrte orudene Skon- ca plasti in tufite. $\mathrm{V}$ povprečju vsebujejo orudeni klastiti $0,38 \%$ živega srebra, približno $50 \%$ v obliki minerala cinabarita, ostalo kot samorodno živo srebro (Č a r , 1998).

S Hg obogatene karbonske plasti gradijo podlago mestnega središča in izdanjajo na pobočju Kurjega vrha in spodnjega dela Pronta, Skonca plasti in tufiti pa izdanjajo na Prontu med Karčnikom in Albrehtom (Č a r, 1998).

$\mathrm{Na}$ območjih, kjer izdanjajo kamnine orudene s Hg, vsebujejo tudi tla naravno povišane vsebnosti živega srebra. Tako območje je npr. Pront, kjer izdanjajo karbonski klastiti s samorodnim živim srebrom.

Iz rezultatov opravljenih raziskav lahko zaključimo, da je Idrija z njeno okolico specifičen primer okolja, ki je zelo obremenjeno z živim srebrom. Predstavlja hvaležen študijski model, ker je na relativno majhnem območju mogoče raziskovati vpliv naravnih (geogenih) virov živega srebra in tistih, ki jih je zaradi petstoletnega pridobivanja $\mathrm{Hg}$ povzročilo ělovekovo delovanje v okolju.

\section{Zahvala}

Za nasvete pri končnem oblikovanju članka sva hvaležna doc.dr. Bojanu Ogorelcu, prof.dr. Simonu Pircu pa za prevod v angleščino. Raziskavo je financiralo Ministrstvo za znanost in tehnologijo RS.

\section{References - Literatura}

Biester, H. \& Gos a r, M. 1999: Določitev zvrsti živega srebra na deponijah prežgane rude v Idriji.- Geološki zbornik, 14, Povzetki referatov, 3-5, Ljubljana.

Biester, H., Gosar, M. \& Covelli, S. 2000: Mercury speciation in sediments affected by dumped mining residues in the drainage area of the Idrija mercury mine, Slovenia.- Environ. Sci. Technol., 34/16, 3330-3336, Washington.

Biester, H., Gosar, M. \& Müller, G. 1999: Mercury Speciation in Tailings of the Idrija Mercury Mine.- Journal of Geochemical Exploration, 65/3, 195-204, Amsterdam.

Byrne, A.R. \& Kosta, L. 1970: Studies on the distribution and uptake of mercury in the area of mercury mine at Idrija, Slovenia.- Vestnik SKD, 17, 5-11, Ljubljana.

Covelli, S., Faganeli, J., Horvat, M. \& B r a m bati, A. 1999: Porewater distribution and benthic flux measurements of mercury and metylmercury in the Gulf of Trieste (Northern Adriatic Sea). -Estuar., coast. shelf sci., 48/4, 415428, London. 
Covelli, S., Faganeli, J., Horvat, M. \& Brambati, A. 2001: Mercury contamination of coastal sediments as a result of long-term cinnabar mining activity (Golf of Trieste, northeren Adriatic sea).- Applied Geochemistry, 16/5, 514558, Amsterdam.

C a r, J. 1985: Razvoj srednjetriasnih sedimentov v idrijskem tektonskem jarku.- 236 str., Doktorska disertacija, Fakulteta za naravoslovje in tehnologijo, Univerza v Ljubljani.

C a r, J. 1998: Mineralized rocks and ore residues in the Idrija region.- In: Idrija as a natural and anthropogenic laboratory, Mercury as a global pollutant, Proceedings, 10-15, Idrija.

D e r m e l j, M. 1974: Idrija spet v središču mednarodne pozornosti.- Idrijski razgledi, $X I X / 3-4$, 126-132, Idrija.

Fergus o n, J.E. \& Kim, N.D. 1991: Trace elements in street and house dusts: Sources and speciation. -The science of the total environment, 100, 125-150, Elsevier Publ. Co., Amsterdam.

Ferrara, R.1999: Mercury mines in Europe: Assessment of Emissions and environmental contamination. In: R. Ebinghaus, R.R. Turner, L.D. de Lacedra, O. Vasiljev, W. Salomons (eds.), Mercury contaminated sites.- Springer-Verlag, 51-72, Berlin.

Förstner, U. \& M üller, G. 1974: Schwermetalle in Flüssen und Seen.- Springer-Verlag, 225 S., Berlin, Heidelberg, New York.

Gn a m uš, A. 1992: Uporaba bioloških indikatorjev za spremljanje in ovrednotenje obremenjenosti kopenskih ekosistemov z živim srebrom.160 str., Ljublana. (Diplomska naloga, Biotehniška fakulteta, Oddelek za biologijo, Univerza v Ljubljani).

Gnamuř, A. \& Hrovat, M. 1999: Mercury in terrestrial food webs of the Idrija mercury mine area. In: R. Ebinghaus, R.R. Turner, L.D. de Lacedra, O. Vasiljev, W. Salomons (eds.), Mercury contaminated sites.- Springer-Verlag, 281-322, Berlin.

Gnamuš, A. Byrne, A.R. \& Horvat, M. 2000: Mercury in the soil-plant-deer-predator food chain on a temperate forest in Slovenia.- Environ. Sci. Technol., 34/16, 3337-3345, Washington.

G o s a r, M. 1992: Ocena vsebnosti živega srebra $\mathrm{v}$ sedimentih Idrijce.- V: Onesnaževanje in varstvo okolja, geologija in tehnika za okolje, zbornik, 213-217, Ljubljana.

G os a r, M. 1997: Zivo srebro v sedimentih in zraku na ozemlju Idrije kot posledica orudenja in rudarjenja.- Doktorska disertacija, Naravoslovnotehniška fakulteta, Univerza v Ljubljani, 125 str., Ljubljana.

Go s a r, M., P irc, S., Š a j n, R., B i d o v e c, M., Mashyanov, N.R. \& Sholupov, S.E., 1997a: Distribution of mercury in the atmosphere over Idrija, Slovenija.- Environ. geochem. health, 19, 101-110, London

Gosar, M., Pirc, S. \& Bidovec, M. 1997b: Mercury in the Idrijca river sediments as a reflection of mining and smelting activities of the mercury mine Idrija.- Journal of Geochemical Exploration, 58, 125-131, Amsterdam.

Gra ši č, M. 1973: Razvoj metode določanja živega srebra v ozračju in standardizacija postopka.- Diplomska naloga, Fakulteta za naravoslovje in tehnologijo, Oddelek za kemijo in kemijsko tehnologijo, Univerza v Ljubljani, 35 str., Ljubljana.
Hes s, A. 1991: Vorläufige Mitteilungen über Schwermetallbelastung der Böden in Umfeld der Quecksilberlagerstätte Idrija (Slowenien).- Geologija, 33, 479-486, Ljubljana.

Hess, A. 1993: Verteilung, Mobilität und Verfügbarkeit von $\mathrm{Hg}$ in Böden und Sedimenten am Beispiel zweier hochbelasteter Industriestandorte.- Heidelberger Geowissenschaftliche Abhandlungen, Band 71, $171 \mathrm{~S}$., Heidelberg.

Horvat, M., Covelli, S., Faganeli, J., L o g a r, M., M a nd ić, V., R a ja r, R., Š irca, A. \& Ž a g a r, D. 1999: Mercury in contaminated coastal environments; a case study : the Gulf of Trieste.-Sci. total environ., 237/238, 43-56.

H orvat, M., J e reb, V., L o g a r, M., F a jon, V.. M i k la včič, V., Kobal, A., H ines, M. \& F a g a n e li, J. 2000: The impact of mercury mining on the environment and human health in the wider Idrija region, Slovenia, and in the Golf of Trieste.- In: J. Nriagu (ed.),11th Annual International Conference on Heavy Metals in the Environment, Contribution \#1140, University of Michigan, School of Public Health, Ann Arbor, MI (CD-ROM).

K a v č i č , I. 1974: Kakšna je stopnja onečiščenosti zraka v Idriji.- Idrijski razgledi, XIX, 1-2, 25-29, Idrija.

Kobal, A., Nanut, E., Stegnar, P., Zvonari č, T.\&H orvat, M. 1991: Ocena vsebnosti živega srebra v zraku in pitni vodi v Idriji (1986).- Idrijski razgledi, XXXVI, 100-102, Idrija.

Kosta, L., B yrne, A.R., Z e l e n k o, V., Stegnar, P., Dermelj V. \& Ravnik V. 1974: Studies on the uptake, distribution and transformations of mercury in living organisms in the Idrija region and comparative areas.- Vestnik SKD, 21, 49-76, Ljubljana.

Kosta, L., R a vnik,V., D e r m elj, M., Pi hlar, B., Stegnar, P., Byrne A.R., Lokar, J., Vakselj, A., Novak, J. \& Prosenc, A. 1978: Mikroelementi v morskih in rečnih sedimentih kot indikatorji kontaminacije slovenskega vodnega sistema.- Vestnik SKD, 25, 463-493, Ljubljana.

Lupšina, V., H orvat, M., Jeran, Z. \& Stegnar, P. 1992: Investigation of mercury speciation in lichens.- Analyst, 117, 673-675, London.

L u p ši n a - M i klav či č, V. 1994: Določanje nizkih koncentracij živega srebra v zraku.Magistrsko delo, Fakulteta za naravoslovje in tehnologijo, Oddelek za kemijo in kemijsko tehnologijo, Univerza v Ljubljani,78 str., Ljubljana.

M i k la v č i č, V.1999: Mercury in the town of Idrija (Slovenia) after 500 years of mining and smelting.- In: R. Ebinghaus, R.R. Turner, L.D. de Lacedra, O. Vasiljev, W. Salomons (eds.), Mercury contaminated sites.- Springer-Verlag, 259-270, Berlin.

M lakar, I. 1967: Primerjava spodnje in zgornje zgradbe idrijskega rudišča.- Geologija, 10, 87-126, Ljubljana.

M l a ka r, I. 1974: Osnovni parametri proizvodnje rudnika Idrija skozi stoletja do danes.Idrijski razgledi, $X I X / 3-4,1-40$, Idrija.

$\mathrm{P}$ a linkaš, L.A., Pirc, S., Miko, S.F., Durn, G., Namjesnik, K. \& Kapelj, S. 1995: The Idrija mercury mine, Slovenia, a semimillennium of continuous operation: an ecological impact.- In: M. R i c h a r d s o n M.(ed.), Environmental toxicology assessment.- Taylor \& Francis, 317-341, London. 
Petkovšek, Z. \& R a kovec, J. 1980: Osnove in smernice za oceno vpliva obnovljenega RŽS na kvaliteto zraka v idrijski kotlini (Katedra za meteorologijo, VTOZD Fizika, FNT), Priloga 2 (36 str.)- V: Brajnik, D., Stegnar, R., Pezdiě, J., Polič, S., Marsel, J., Rakovec, J., Petkovšek, Z., Dular, M., Mejač, B. \& Novak, P.: Investicijski program obnove proizvodnje $\mathrm{Hg}$, Ekološki vidiki obnovitve proizvodnje Hg v Idriji, S-DB-MS/80, Izdelali IJS in SEPO.

P i r c, S. 1991: Živo srebro v ozračju nad Idrijo in okolico.- Idrijski razgledi, XXXV/1-2, 111112 , Idrija

P i r c, S., 1993: Regional geochemical surveys of carbonate rocks; final report; USG Project Number JF881-0.- 30 str. Ljubljana.

P l a c e r, L. \& C a r, J. 1977: Srednjetriadna zgradba idrijskega ozemlja.- Geologija, 20, 141166, Ljubljana.

Schlipkoeter, H.W. \& Brockhaus, A. 1988: Experience in the appraisal of health risks owing to soil contamination. -In: Wolf, K., Van den Brink, W.J. \& Colon, F.J., (eds.), Contaminated soil '88, 403-414, Kluwer Academic Publishers, Dordrecht, Netherland.
Stegna r, P. 1973: Privzem Hg in njegova porazdelitev $\mathrm{v}$ rastlinah in živalih.- Magistrsko delo, Biotehniška fakulteta, Oddelek za biologijo, Univerza v Ljubljani, 58. str., Ljubljana.

Š a jn, R. 1999: Geokemične lastnosti urbanih sedimentov na ozemlju Slovenije.- Geološki zavod Slovenija, 136 str., Ljubljana.

Sirca, A., Horvat, M., Covelli, S., Ž a gar, D. \& F a ganeli, J. 1999a: Estimation of mercury mass balance in the Gulf of Trieste.- Acta Adriat., 40 (2), 75-85.

Sirca, A., R a ja r, R., R e ed C. H. \& H o r v a t, M. 1999b: Mercury transport and fate in the Golf of Trieste (Northeren Adriatic) - a two-dimensional modelling approach.- Environmental Modelling \& Software, 14, 645-655, Amsterdam.

UR A D N I L IS T R S, 1996: Uredba o mejnih, opozorilnih in kritičnih imisijskih vrednostih nevarnih snovi v tleh.- Uradni list, 68, 5773-5774, Ljubljana.

W H O, 1990: Environmental health criteria 101, Methylmercury.- World Health Organization, 144 pp., Geneve. 